This dissertation has been

$64-7065$

microfilmed exactly as received

TOY, Janet Posey, 1930-

METABOLIC PATHWAYS IN ACID PRODUCTION

BY THE YEAST HANSENULA ANOMALA.

The Ohio State University, Ph.D., 1963

Botany

University Microfilms, Inc., Ann Arbor, Michigan 


\title{
METABOLIC PATHWAYS IN
}

ACID PRODUCTION BY

THE YEAST HANSENULA ANOMALA

\author{
DISSERTATIOIN \\ Presented in Partial Fulfillment of the Requirements \\ for the Degree Doctor of Philosophy in the \\ Graduate School of the Ohio State \\ University
}

By

Janet Posey Toy, A.B., M.S.

The Ohio State University

1963

Approved by

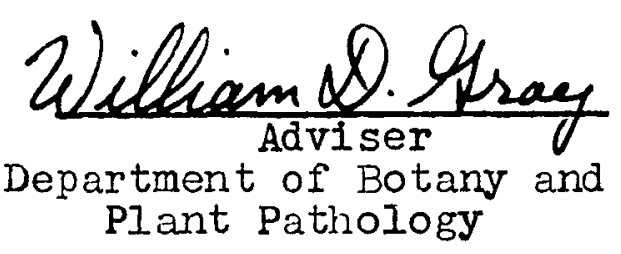




\section{ACKNOWLEDGMENTS}

I wish to express my appreciation for the continuing advice and encouragement given to me by Dr. William D. Gray throughout the course of this investigation. Dr. Gray, Dr. Bernard S. Meyer, and Dr. Clyde C. Allison were very helpful in their criticism of the manuscript. I am grateful also for financial help received from the research fund of the Ohio Academy of Science and from the American Association of University Women, which granted me the Dorothy Bridgman Atkinson Fellowship in 1961-1962.

Wittenberg University was most generous in permitting me to use laboratory facilities there. Dr. W.C. Beaver of the biology department at Wittenberg kindly shared research space and contributed much helpful assistance. 


\section{TABLE OF CONTENTS}

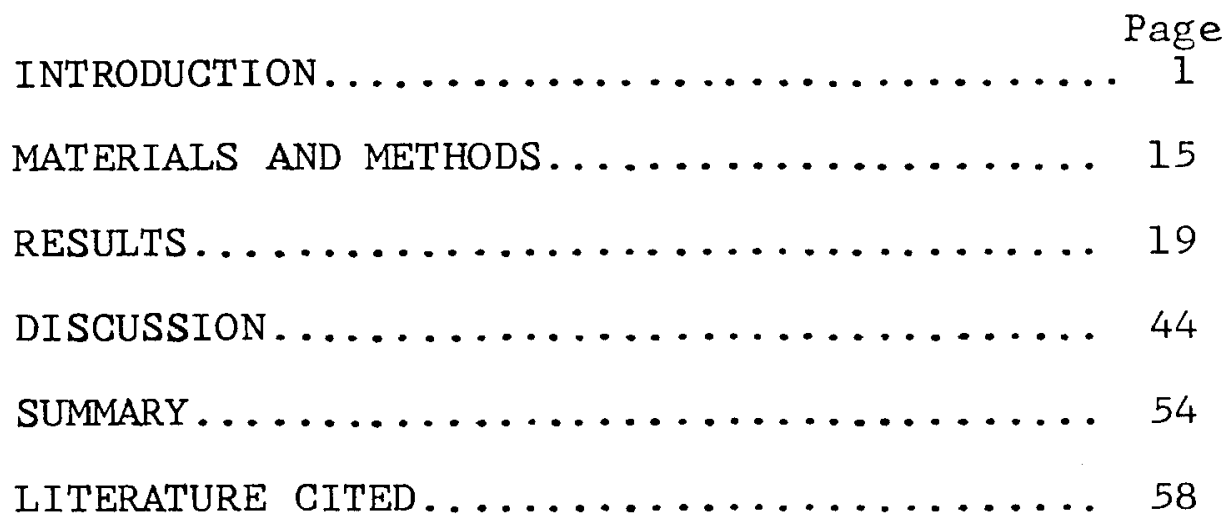




\section{LIST OF TABLES}

Table Page

1. Composition of basal medium........... 17

2. Acid production by $\mathrm{H}$. anomala under different hydrogen Ion concentrations and length of incubation period......... 20

3. Effect of glycolytic inhibitors on production of acid................. 23

4. Effect of sodium iodoacetate on acid production....................... 25

5. Effect of sodium iodoacetate on acid production at different glucose concentrations................... 26

6. Effect of potassium cyanide on acid production................... 27, 28

7. Effect of atabrine and potassium cyanide on acid production.................. 30

8. Effect of graded concentrations of glucose and fructose on acid and acetate

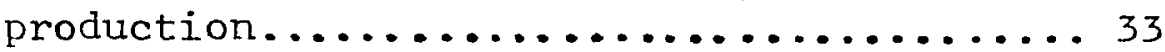

9. Acid and acetate production over a ten day period......................... 34

10. Acid and acetate levels after twenty days.. 42 


\section{LIST OF ILLUSTRATIONS}

Figure

Page

1. Acid production on ten per cent

glucose over a ten day period.......... 35

2. Acid production on ten per cent

fructose over a ten day period......... 36

3. Production of total acid over a

ten day period....................... 37

4. Production of volatile acid over

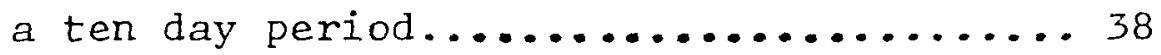

5. Production of non-volatile acid over a ten day period................ 39

6. Ethyl acetate synthesis over a ten

day period....................... 40 


\section{INTRODUCTION}

The yeast cell has proved to be a useful organism for physiological studies. Saccharomyces cerevisiae, the yeast important to the baking and brewing industries, has been used most often; however, more recently some of the lesser known yeasts have been studied. One of these is Hansenula anomala Hansen (Sydow).

Some initial studies on the physlology of the genus Hansenula, and $\underline{H}$. anomala in particular, indicated that an ester $1 \mathrm{~s}$ produced. Finding a lack of definite information on the amount and identity of the metabolic products of H. anomala, Gray (1949) Investigated conditions necessary for ester synthesis and isolater. the volatile metabolic products ethyl acetate, ethyl alcohol, and acetaldehyde. He found that, after the ester had reached its maximum concentration, it disappeared from the medium at about the same rate it was produced. Apparently the ester is metabolized by the yeast.

Gray (1949) also revlewed the results of early phys lological research on ester production by Hansenula 
species, which dated back to 1894 . Before discussing experimental work subsequent to that of Gray, it may be profitable to explore the cytological and physlological character1st1cs oi' the yeast Hansenula.

The fungus used in the present investigation is Hansenula anomala (Hansen) Sydow. The genus Hansenula Is generally classified as an Ascomycete, family Saccharomycetaceae (ascosporogenous yeasts), subfamily Saccharomycetoldeae, tribe Saccharomyceteae. Ascosporogenous yeasts are characterized by (1) naked asci resulting directly from confugation of two vegetative ce11s, and (2) lack of a dicaryon state, a vegetative state in which each cell contains two nucle1 which divide synchronically during cell divisions. (Lodder et a1., 1958.)

The genus Hansenula includes all ascosporogenous yeasts which can assimilate nitrate. The genus was redefined by Wickerham (1951) as: "Yeasts which reproduce asexually by budding, or by budding accompanied by the formation of pseudohyphae or true hyphae, form 1-4 ascospores per ascus, and assimilate nitrate. The spores are mainly hat-shaped or Saturn-shaped. The ascus usually ruptures at maturity to 11berate the spores." 
The species Hansenula anomala is the prototype of the genus as described by early investigators. The ascospores are hat-shaped, usually with a thick brim. There is a wide raige of cell shape and size. The cells occur singly, in pairs, or in chains.

The species exhibits pelicle formation, fermentation of glucose and sucrose, pseudomycelium formation, ester formation, and splitting of the B-glucoside arbutin. Maltose is almost always fermented, while the ability to ferment galactose and raffinose depends on the strain. No added vitamins are needed for growth.

H. anomala is the most widely distributed member of the genus. It has been isolated from many sources: fruits, brine, so11, saps and gums of trees, cocoa beans, and as a predominant organism in bin-stored rice. It is an occasional contaminant in industrial food and fermentation processes.

Candida pelliculosa is the imperfect stage of $\underline{H}$. anomala. Before this was demonstrated by mating the two, C. pelliculosa was 1solated from human sources, part1cularly cases of disease of the pulmonary tract. $\underline{H}$. schneggil is considered by some workers to be another 
sexually active mating type of $\underline{H}$. anomala, although W1ckerham (1951) considers it a separate species represented by a single strain.

The life cycle of $\underline{H}$. anomala is similan to the pattern found in Saccharomycodes ludw1g11 as discussed by Alexopoulos (1952). It exhibits a long diploid somatic stage and a very short haplo1d stage. The ascospores copulate, with conjugation occurring at the time the ascospores germinate. No conjugation takes place immediately preceding the formation of asc1. Asc1 rupture as the ascospores mature, except in some strains having cells large enough to accomodate the mature spores. Two ascospores fuse, with both plasmogamy and karyogamy taking place, and form a diplo1d cell. Melosis converts these diplo1d somatic yeast cells into asc1, each producing haplold ascospores, usually four in number. The ascospores represent the only haplo1d phase of the life cycle. Wickerham (1951) and Wickerham and Burton (1954) have worked out phylogenetic Iines in the genus Hansenula. They recognize lines of development from primitive specles to more highly evolved specles. 
W1ckerham suggests three lines of development in the genus, as shown by his phylogenetic diagram:

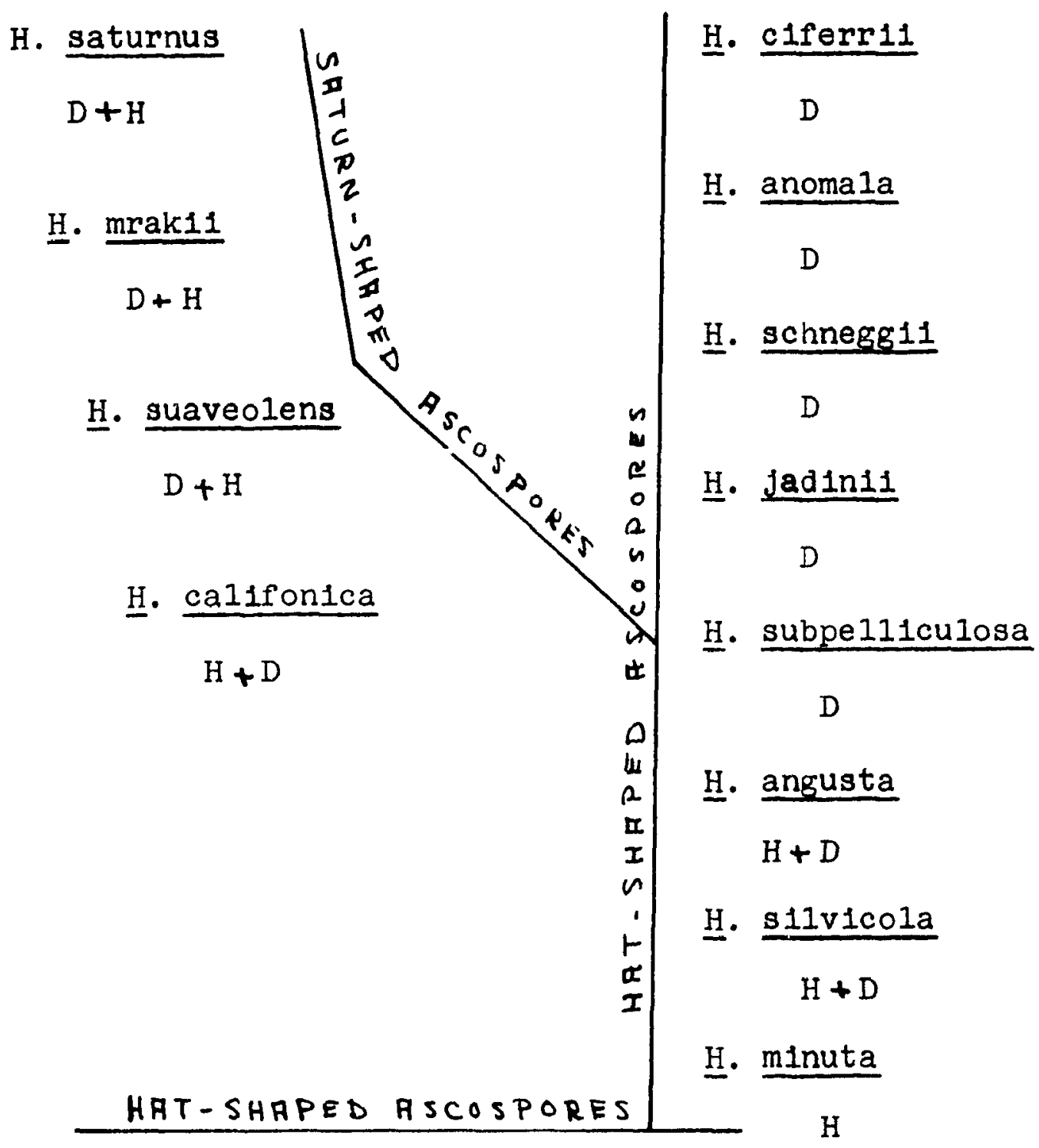

H. canadensis $\quad$ H. beck11 $\frac{H}{D} \cdot \frac{\text { capsulata }}{H}$

In the above dlagram, the following symbols are used:

$H$, haplo1d; $D$, diplo1d; $H+D$, more haplo1d than diplo1d;

$D+H$, more diplo1d than haplo1d (based on Wlckerham, 1951). 
The lower line shows a loss in physlological activity as the nucleus became diplold. The three species in this line are found exclusively in coniferous trees. $\underline{H}$. capsulata is entirely haplo1d and ferments glucose slowly; the other two are diplold but ferment no sugars. All three require an external source of vitamins.

The vertical branch of the phylogenetic line is made up of specles which also produce hat-shaped ascospores, but are not isolated from conffers. As the ratio of diploid to haploid cells increases from species to species, there is less dependence on an external source of vitamins. There is an increase in the number of sugars fermented and the intensity of fermentation. $\underline{\text { H. minuta }}$ produces asc1 as a result of the conjugation of a cell with 1ts own small bud. Th1s appears to be a characteristic which decreases with the change to a diplo1d somatic stage.

H. anomala occuples an intermediary position. It produces esters, a characteristic not shared by the three specles at the bottom of this line, and is active in fermentation of sugars and utilization of alcohol and 
organ1c ac1ds. It exhibits a more advanced type of confugation, that of germinating ascospores.

The third phylogenetic branch, shown diagonally on the dlagram, consists of specles having Saturn-shaped spores. Wickerham considers them to cover a relatively recent period of evolution, since none is completely haplold or completely diplo1d. They show the same general trends physlologically as the specles with hat-shaped ascospores discussed above. Confugation of adult vegetative cells occurs in all of these species and is generally isogamic. Only $\underline{H}$. californica in this series requires the addition of vitamins to a synthetic medium.

W1ckerham conslders the most fundamental trend In these phylogenetic relationships to be the progressive development from a haplold nucleus, in the more primitive yeasts, to the diplold condition found in the more recently evolved specles.

Other characteristics showing such trends are: from vitamin dependence to independence, from no fermentation to fermentation of a variety of sugars, from no pelilcle formation on a liquid medium to pellicle 
formation. The ab111ty to form hyphae generally increases as the species become more diplold.

The most primitive type of confugation in iansenula appears to be that of a large cell and 1 ts small bud. Successively higher levels of development include heterogamy of independent cells, 1sogamy of Independent cells, and conjugation of germinating ascospores or the ir Immediate descendants. Another high form of conjugation is nuclear fusion within a germinating ascospore. The three methods of confugation named first take place at the end of the vegetative stage of haploid cells; the remalning types occur at the beginning of the vegetative stage of the yeast cells which exist as diploid cells in the vegetative stage. In developing the theory of phylogenetic lines In Hansenula, Wickerham is in opposition to the theory of Gu1lllermond (1937), who belleved that haplo1d and diplold yeasts represent two separate lines of development, with the haplo1d yeasts arising from a form similar to Eremascus, and the diploid yeasts developing from Taphrina. According to Guililermond (1940), the true yeasts have been derived from the mycellold forms by reduction. 
Many mycologists consider the yeasts and related forms to be primitive groups, perhaps showing evolution In their development from primitive to more recently evolved forms. Other workers conslder them to be reduced, degenerate forms which represent the highest stage in the development of the Ascomycetes. Physlologlcal studies with $\underline{H}$. anomala were continued in 1951 by a group Including Davles and Peel, who identified acetic acid and detected a non-volatile acid, which was not identifled, among the metabolic products of the organism. Tabachnick (1951), using chromatographic methods, detected acetic, malic, succinic, citric, and fumar1c acids in the yeast ce11s. Hughes (1952) found only two acids produced by fermentation by $\underline{H}$. anomala: volatile acetic acid and a non-volatile acld which was not identified. His investigation showed that this acid was not saturated, contalned only one acidic group, and decomposed without melting at $212-217^{\circ} \mathrm{C}$. No ac1ds with these characteristics were listed in avallable tables of derivatives. Davies et a1. (1951) reported that the acld did not prove to be pyruvic, lactic, or succinic. 
Brock (1952) studied the effects of Inhibitors on resplration in $\underline{H}$. anomala. Observing that certain Inhibitors of glycolysis and the tricarboxylic acid cycle did not appear to inhibit respiration, he suggested that an alternate pathway might exist. Th1s pathway of carbohydrate metabolism was suggested to be similar to that demonstrated by Warburg, I.1pmann, and Dickens, with others, and sometimes named for them. This is also called a pentose phosphate pathway or a hexusemonophosphate shunt. Together with glycolysis, it w111 be discussed more fully later.

We may 1liustrate the two possible pathways of carbohydrate metabolism thought to occur in yeast by the following diagram. The glycolytic pathway is often called an Embden-Meyerhof-Parnas scheme (EMP) after workers who demonstrated 1ts existence. We may abbreviate the hexosemonophosphate shunt as HMP. 

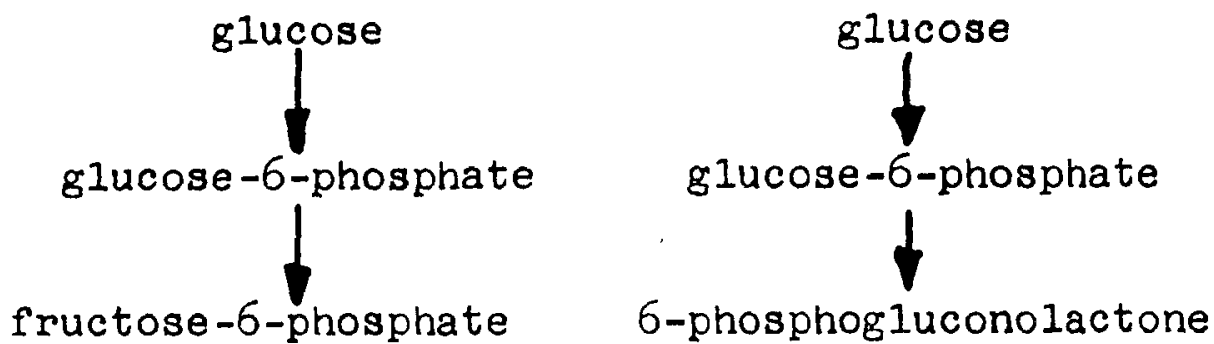

fructose-6-phosphate

6-phosphogluconolactone
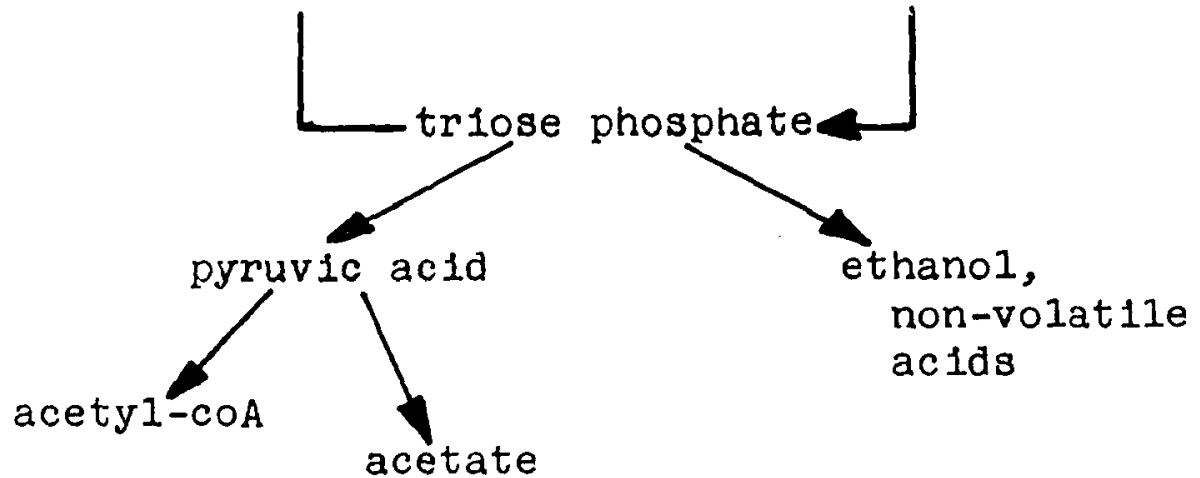

Whether or not the triose phosphate (glyceraldehyde-3phosphate) produced from the two painways forms a pool, as has been assumed, is not known. There is a possibility that there is intermixing between the two pathways (Horecker and Mehler, 1955).

The hexose-monophosphate pathway is well known to occur in yeast. Not only does it provide a route for the respiration of hexoses and pentoses, it also contributes to the synthesis of ribose, found in nucleic acids. 
The results of Davis (1958) Indicate that both glycolytic and hexose-monophosphate pathways are simultaneously active in $\underline{H}$. anomala. Unpublished data by Gray Indicate this a1so, as does the work of Sova (1960). Sova also substantlated the probable intermixing of both pathways.

The phosphorylation of glucose, fructose, glucosamine, and mannose all depends on the enzyme hexokinase. The rate of phosphorylation of these sugars can be determined for each of these alone by saturating yeast hexokinase with each. When these are added simultaneously to the enzyme system, the total activity is far less than would be expected if a summation of individual activities was taking place. This may be due to a competitive inhibition between the sugars for the active center of the enzyme (Axelrod, 1960).

Recent unpublished results by Gander with lsolated enzyme systems indicate that fructose has an inhibitory effect on the enzyme systems of glycolysis. This inhibition may occur at one of the first steps in the glycolytic pathway, catalyzed by hexokinase. 
Acetate formed in respiration by yeasts, elther directly by the glycolytic pathway, or by the oxidation of ethanol formed by the hexose-monophosphate shunt, can be further catabolized. This would take place possibly by the tricarboxy11c ac1d cycle; most of the intermediate compounds of the cycle have been found in yeast. The mechanism of the Krebs tricarboxylic acid cycle, or citric acid cycle, has been clarifled by the work of Lipmann, Ochoa, and others. Novell1 and Lipmann (1947, 1950) observed that yeasts deficient in pantothenic acid do not utilize acetate as effectively as non-deficlent yeasts. Coenzyme $A$, which contains pantothenic acid as part of 1 ts structure, was found to be concerned with the primary attack on acetate, presumably a condensation with oxalacetate to form citric acid. These investigators confirmed the catalytic function of coenzyme A in citric acid synthesis with cell-free extracts of yeast. Activation of a two-carbon, or acety1, fragment produced in respiration by coenzyme $A$ is important in the composition of many major cell constituents: fats, phospholipids, proteins, and polysaccharides. The acetyl group, formed from pyruvic acid, a common intermediary in sugar oxidation, is a basic building block in blosynthesis. 
The alms at the investigation, then, were two-fold:

(1) To block elther the glycolytic pathway or the hexose-monophosphate shunt by using specific inhibitors of each, and (2) to determine whether an unknown nonvolatile acld previously reported in $\underline{H}$. anomala might be produced by the hexose-monophosphate shunt or by a glycolytic mechanism. 


\section{MATERIALS AIND METHODS}

The basal medium used by Kuehner (1951) and later by ringhes (1952) in their studies with Hansenula anomala was modified for use in the present investigation because it is a chemically definable medium.

Hansenula anomala (Hansen) Sydow, strain IJumber 20 of the Ohio State University stock culture collection, was used throughout this investigation.

In preparing inoculurn for use in these studies, a $25 \mathrm{ml}$. portion of basal mediun was autoclaved at 15 pounds pressure for 20 minutes, cooled, and inoculated with a loop needile from a slant of $\underline{H}$. anomala. Slants of the yeast were cultured on the Iollowing medium: 0.7 per cent Difco Yeast Extract, 0.5 per cent $\mathrm{KH}_{2} \mathrm{PO}_{4}, 5.0$ per cent glucose, and 3.0 per cent agar agar. The liquid culture vas incubated without agitation for 24 hours at $30^{\circ} \mathrm{C}$. At the end of the incubation period, $1 \mathrm{ml}$. portions of this inoculum were used to inoculate $100 \mathrm{ml}$. of basal medium in $250 \mathrm{ml}$. erlenmeyer flasks.

During the course of the investigation, various alternate methods for culturing were tested. One of these studies used successive transfers on liquid media insterd of slants for growing inoculum; no denonstrable difference in results 
was observed. Other studies using varying amounts of medium in different sizes of flasks were planned to test the effects of aeration. Additional tests showed that a $\mathrm{pH}$ of the basal medium of 6.2 before autoclaving seemed to promote best acid production, and that $30^{\circ} \mathrm{C} . \pm 20$ was optinal for acid production. Length of culture period was studied; a high total acid production was obtained at seven and eight days. Eight days was the length of incubation in most of the investigation except where exceptions are noted.

The medium as used by Hughes (1952) contoined 2 per cent slucose. In attempting to secure maximum total acid production this was raised to 4, 5, and 10 per cent glucose. The final ailount is shown in Table 1, listing the composition of the medium.

When inhibitors were used, knom molar solutions were made up and added 24 hours before harvest, except in the studies vith fructose, where it was incorporated into the medium as will be indicated later.

Total acidity was determined by titration of $5 \mathrm{ml}$. aliquots of the fermentation medium (diluted with $25 \mathrm{ml}$. of carbon dioxide-free water) with 0.1000 in $\mathrm{NaOH}$ using phenolphthalein as indicator, and was expressed as milliliters of normal acid per $100 \mathrm{ml}$. of fermentation mediun. 
Table 1.--Composition of basal medium.

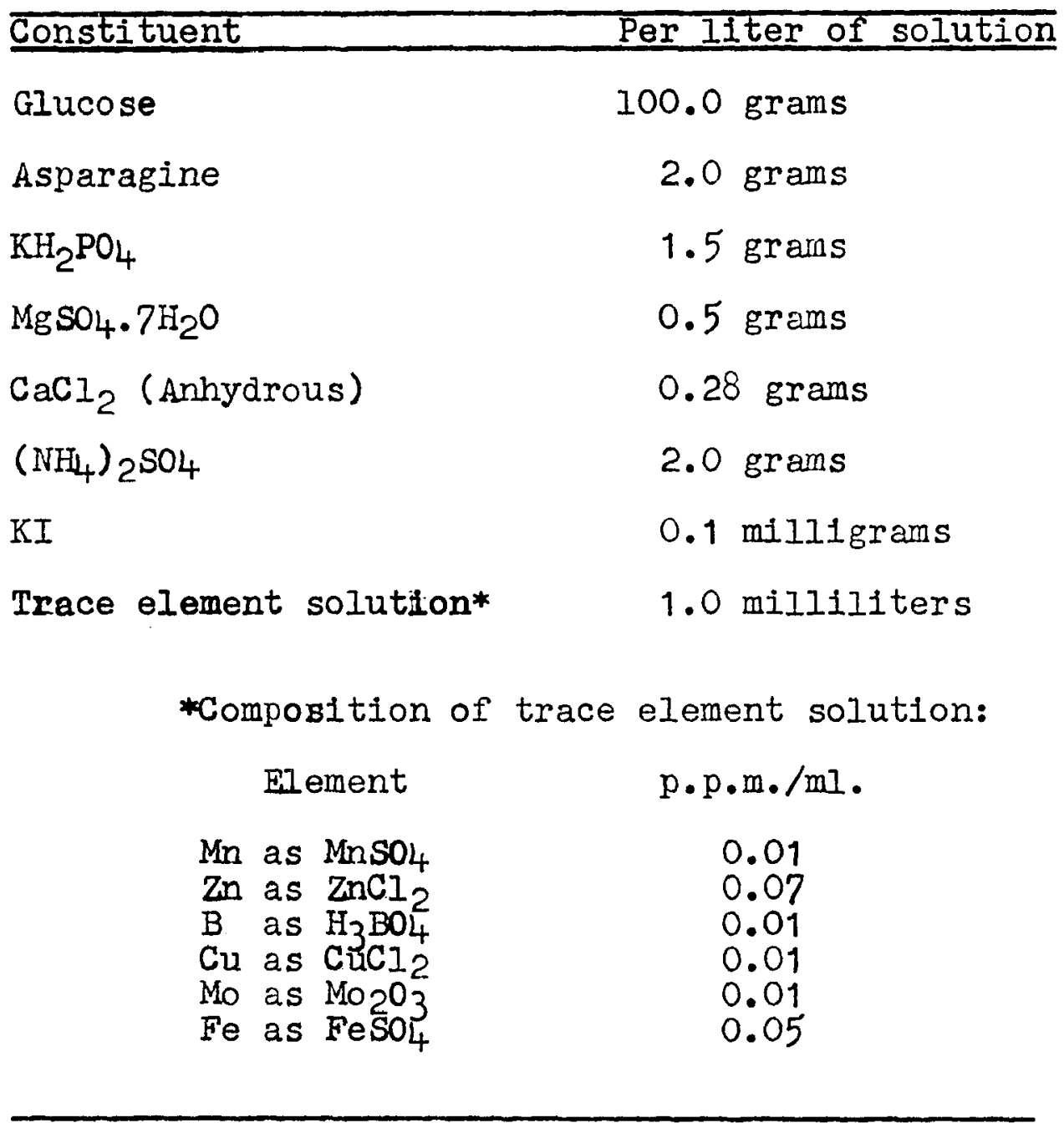


Volatile acid was determined in the following manner: $5 \mathrm{ml}$. of the fermentation medium and $0.5 \mathrm{ml} .10$ per cent phosphoric acid were put into a Sellier tube in a modified Hortvet apparatus and $100 \mathrm{ml}$. Of steam distillate was collected. This distillate was tilen titrated with $0.1000 \mathrm{~N} \mathrm{NaOH}$ with phenolphthalein as indicator. Ion-volatile acid was determined as follows: acidity due to non-volatile acid = total acidity minus volatile acidity.

For ethyl acetate determination a $50 \mathrm{ml}$. sample was removed from the culture. About $25 \mathrm{ml}$. of this sample were distilled into a $500 \mathrm{ml}$. erlenmeyer flask, and a few drops of phenolphthalein were added. The distillate was neutralized with 0.1 if iral until the color was just pink to phenolphthalein. Twenty-five $\mathrm{ml}$. of $0.1000 \mathrm{If} \mathrm{NaOH}$ were added to the neutralized distillate and refluxed for one hour. The distillate was cooled and titrated with $0.1000 \mathrm{iN}$ HCI. Total ethyl acetate production per flask in milligrams was calculated as follows: (25 ml. - No. of $\mathrm{ml}$. of $\mathrm{HCl}) \mathrm{x}$ $3.8 \times 2$. 
RESULTS

I. Preilminary investigations

A number of screening tests were conducted to determine how to obtain optimum total acid production. These were explained in detail in the preceding section and were concerned with length of culture period, temperature requirements, $\mathrm{pH}$ of the medium, area of the culture flask and other factors influencing aeration, and amount of glucose in the medium (Table 2). Studies were a1so made on the best method of preparing inoculum.

\section{Inh1b1tors}

The second area of investigation was concerned with the effect of various inhibitors on the production of volatile and non-volatile ac1ds. Inhibitors were selected which were known to inhibit the metabolic pathways at specific points, as will be indicated. With all of these agents, a series of screening surveys were made to determine what concentrations would have the greatest effect. 
TABLE 2.--Acid production by Hansenula anomala under different hydrogen ion concentrations and length of incubation period. PH of the medium before inoculation is given. Figures represent the average of six flasks in each trial.

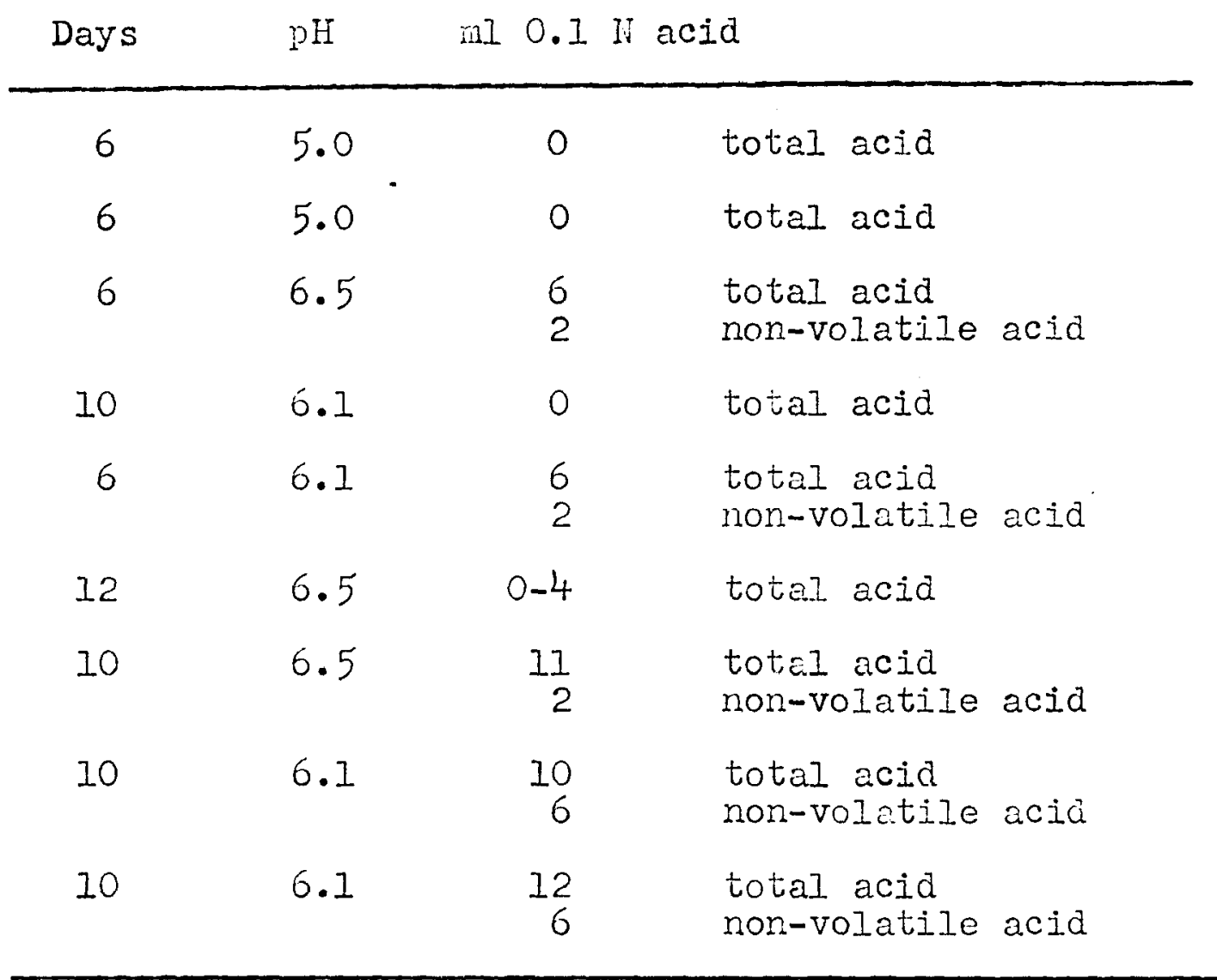

liedium in above trials is basal medium with two per cent glucose. 
Genera11y a relatively weak concentration was used to begin w1th, and successively stronger solutions were then used. In some cases, there were Indications in the Iiterature as to what concentration might be used as a starting point.

A list of the inhibitors used and their probable place of action in the metabolic pathways may be helpful In visualizing the attack on the problem.

The Inhibitors known to affect glycolysis include fluoride, lodoacet1c acid, 2,4-dinitrophenol, and sodium bisulfite. The hexose-monophosphate shunt is inhibited by cyanide and atabrine.

III. Results of investigations with inhibitors

(1) Screening tests as to concentration were begun with a concentration of $10^{-5} \mathrm{M}$ and with some inhibitors were gradualiy reduced to a concentration of $10^{-0.25} \mathrm{M}$. These will be indicated speciflcally in the next section. It must be kept in mind that at the stronger concentrations there may be side effects of any polson which would have an overall effect on the metabolism of the cell.

(2) As indicated above, the inhibitors affecting 
glycolysis are fluoride, 2,4-dinitrophenol, sodium blsulfite, and lodoacetic acid. If these inhibit glycolysis at any point, we might expect an increase in non-volatile acid coming down through the alternate metabol1c pathway, the hexose-monophosphate shunt.

W1th both sodium fluoride and 2,4-dinitrophenol, results with concentrations of $10^{-4} \mathrm{M}$ in each case showed an increase in non-volatile acid over that of the control. In no case was there a complete blocking of glycolysis; some volatile acld was always produced. This was true of a11 the glycolytic inhibitors (Table 3).

In the case of sodium blsulfite, results were somewhat inconclusive, with amounts of total acld obtained varying widely, and with no definite ratios of volatile and non-volat1le acids belng observed.

Some of the most promising results came with the use of the sodium salt of lodoacetic acid. This poison is belleved to Inhibit triosephosphate dehydrogenase, an enzyme in the glycolytic pathway.

With sodium lodoacetate in concentrations as small as $10^{-2} \mathrm{M}$, an increase in the amount of non-volatile acid over that of the control was noted. Further tests used sodium 
TABLE 3.--Effect of glycolytic inhibitors on production of acid. TA = total acidity; NVA = non-volatile acidity; these are expressed as $\mathrm{ml} 0.1 \mathrm{~N}$ acid/ $100 \mathrm{ml}$. The basal mediun contained two per cent glucose. Figures represent an average of three flasks per trial.

Coritiol

TA TVA

trial 1 12.5n $6 \mathrm{ml}$

214.0

6 with inhibitor

TA IVA

$18 \mathrm{mI} \quad \% .5 \mathrm{mI}$

$20 \quad 9.0$

2,4-dinitrophenol $\left(10^{-4}\right)$ as inhibitor

\begin{tabular}{rlcccc} 
& \multicolumn{2}{c}{ control } & \multicolumn{2}{c}{ with inhibitor } \\
TA & IVA & TA & IVA \\
2 & $14 n I$ & $6 \mathrm{ml}$ & $26 \mathrm{nI}$ & $13 \mathrm{nI}$ \\
211 & 6 & 21 & 11
\end{tabular}


lodoacetate in successively increasing concentrations up to $10^{-0.25} \mathrm{M}$. The best results in increasing the nonvolatile acid/volatile acid ratio over that of the control were obtained at this concentration (Tables 4 and 5).

(3) Inhibitors thought to affect the hexosemonophosphate pathway through the cytochrome system are cyanide and atabrine.

If these are effective inhibitors, we might expect a low amount of non-volatile acid produced with a corresponding increase in the amounts of volatile acid produced. Potassium cyanide was used in a gradient of concentrations from $10^{-5} \mathrm{M}$ to $10^{-0.25} \mathrm{M}$. Some indications of a low non-volatile ac1d/volatile acid ratio were observed at the weaker concentrations. This effect became pronounced at a concentration of $10^{-1} \mathrm{M}$ and continued to appear at stronger concentrations (Table 6).

Atabrine is another inhibitor of the monophosphate shunt mechanism, although it blocks the pathway at an earlier point than cyanide does.

Atabrine was observed to lower the non-volatile acid/ volatile acid ratio at concentrations of $10^{-3} \mathrm{M}$ and $10^{-2} \mathrm{M}$. 
TABLE 4.--Ifiect of the glycolytic inhibitor sodium iodoacetate on acid production. Acidity is expressed as $\mathrm{ml} 0.1$ is acid/ $100 \mathrm{ml}$. TA = total acidity; IVA = non-volatile acidity. Fieures represent the average of three flasks in each trial. Per cent glucose in the basal inediun is given.

$2 \%$ glucose

control $10^{-2}$ in iodoacetate as inhibitor

$\begin{array}{llllll} & & \text { TA } & \text { IVA } & \text { TA } & \text { IVA } \\ \text { trial } & 1 & 20 \mathrm{nl} & 11 \mathrm{ml} & 31 \mathrm{ml} & 8 \mathrm{ml} \\ & 2 & 32 & 10 & 35 & 22\end{array}$

$2 \%$ glucose

control

10-1 $\mathrm{W}$ iodoacetate as inilibitor

$\begin{array}{rrrrr} & \text { IA } & \text { IVA } & \text { TA } & \text { NVA } \\ 1 & 9 & 7 & 15 & 7 \\ 2 & 13 & 7 & 15 & 11 \\ 3 & 22 & 12 & 20 & 13 \\ 4 & 20 & 8 & 27 & 11\end{array}$

$4 \%$ Elucose

$\begin{array}{lllll}1 & 24 & 13 & 43 & 31 \\ 2 & 45 & 36 & 46 & 33\end{array}$

$5 \%$ Elucose

$\begin{array}{lllll}1 & 36 & 26 & 19 & 17 \\ 2 & 44 & 36 & 38 & 30\end{array}$

$10 \%$ glucose

$\begin{array}{lllll}1 & 41 & 25 & 45 & 17 \\ 2 & 26 & 12 & 46 & 40 \\ 3 & 40 & 36 & 14 & 10\end{array}$


TABLE 5.--Effect of the glycolytic inhibitor sodium iodoacetate on acid production at different glucose concentrations. Aciajity is expressed as $\mathrm{ml} 0.1 \mathrm{~N}$ acid/ $100 \mathrm{ml}$. TA = total acidity; NVA = non-volatile acidity; $V A=$ volatile acidity. Figures represent the average of three flasks in each trial.

\begin{tabular}{|c|c|c|c|c|c|c|c|c|}
\hline & & \multicolumn{3}{|c|}{ control } & \multicolumn{4}{|c|}{$\begin{array}{l}10^{-0.5} \mathrm{M} \text { iodoacetate } \\
\text { as inhibitor }\end{array}$} \\
\hline & $\begin{array}{l}\mathrm{T} \\
\mathrm{m}\end{array}$ & $\begin{array}{c}\text { NVA } \\
\mathrm{mI}\end{array}$ & $\begin{array}{l}\mathrm{VA} \\
\mathrm{mI}\end{array}$ & $\begin{array}{l}\text { INVA } / \mathrm{VA} \\
\text { ratio }\end{array}$ & $\begin{array}{l}\mathrm{TA} \\
\mathrm{mI}\end{array}$ & $\begin{array}{l}\text { IVAA } \\
\mathrm{mI}\end{array}$ & $\begin{array}{l}\text { VA } \\
\text { mI }\end{array}$ & $\begin{array}{l}\text { NVA/VA } \\
\text { ratio }\end{array}$ \\
\hline $\begin{array}{r}4 \% \text { glucose } \\
\text { trial }\end{array}$ & $\begin{array}{ll}1 & 2 \\
2 & 4 \\
3 & 5\end{array}$ & $\begin{array}{l}13 \\
36 \\
26\end{array}$ & $\begin{array}{r}11 \\
9 \\
30\end{array}$ & $\begin{array}{l}1.0: 1 \\
4.0: 1 \\
0.8: 1\end{array}$ & $\begin{array}{l}63 \\
45 \\
54\end{array}$ & $\begin{array}{l}24 \\
35 \\
31\end{array}$ & $\begin{array}{l}39 \\
10 \\
23\end{array}$ & $\begin{array}{l}0.60: 1 \\
3.50: 1 \\
1.25: 1\end{array}$ \\
\hline \multirow[t]{2}{*}{$5 \%$ glucose } & 3 & 29 & 6 & $5: 1$ & 20 & 12 & 8 & $1.50: 1$ \\
\hline & $\begin{array}{ll}1 & 2 \\
2 & 6\end{array}$ & $\begin{array}{l}13 \\
56\end{array}$ & $\begin{array}{r}16 \\
8\end{array}$ & $\begin{array}{l}1: 1 \\
7: 1\end{array}$ & $\begin{array}{l}32 \\
36\end{array}$ & $\begin{array}{l}76 \\
32\end{array}$ & $\begin{array}{r}16 \\
4\end{array}$ & $\frac{1}{8}: 1$ \\
\hline & & \multicolumn{3}{|c|}{ control } & \multicolumn{4}{|c|}{$\begin{array}{c}\text { 10-0.25 in iodoacetate } \\
\text { as inhibitor }\end{array}$} \\
\hline $10 \%$ glucose & $\begin{array}{ll}1 & 4 \\
2 & 3 \\
3 & 3\end{array}$ & $\begin{array}{l}32 \\
32 \\
28\end{array}$ & $\begin{array}{r}8 \\
4 \\
10\end{array}$ & $\begin{array}{r}4: 1 \\
8: 1 \\
2.8: 1\end{array}$ & $\begin{array}{l}28 \\
28 \\
24\end{array}$ & $\begin{array}{l}20 \\
26 \\
20\end{array}$ & $\begin{array}{l}8 \\
2 \\
4\end{array}$ & $\begin{array}{r}2.5: 1 \\
13 \cdot 0: 1 \\
5.0: 1\end{array}$ \\
\hline
\end{tabular}


TABLE 6.--Effect of potassium cyanide on acid production at different glucose concentrations. Acidity is expressed as $\mathrm{ml} 0.1 \mathrm{~N}$ acid/ $100 \mathrm{ml}$. TA = total acidity; IVA = nonvolatile acidity; $\mathrm{VA}=$ volatile acidity. Figures represent the average of three flasks in each trial.

\begin{tabular}{|c|c|c|c|c|}
\hline \multirow{2}{*}{$\begin{array}{l}2 \% \text { glucose } \\
\text { trial }\end{array}$} & \multicolumn{2}{|c|}{ control } & \multicolumn{2}{|c|}{$\begin{array}{l}\mathrm{KCN} 10^{-4} \mathrm{M} \\
\text { as inhibitor }\end{array}$} \\
\hline & $\frac{\mathrm{TA}}{\mathrm{mI}}$ & $\frac{\mathrm{HVA}}{\mathrm{mI}}$ & $\frac{T A}{m I}$ & $\frac{\text { IVA }}{\mathrm{mI}}$ \\
\hline$\frac{1}{2}$ & $\begin{array}{l}14 \\
11\end{array}$ & $\begin{array}{l}6 \\
6\end{array}$ & $\begin{array}{l}18 \\
18\end{array}$ & $\begin{array}{l}0 \\
0\end{array}$ \\
\hline & \multicolumn{2}{|c|}{ control. } & \multicolumn{2}{|c|}{$\mathrm{KCN} 10^{-3} \mathrm{M}$} \\
\hline . & $\begin{array}{r}4 \\
19\end{array}$ & 12 & $\begin{array}{r}4 \\
20\end{array}$ & $\begin{array}{l}0.7 \\
3.3\end{array}$ \\
\hline & \multicolumn{2}{|c|}{ control } & \multicolumn{2}{|c|}{$\mathrm{KCN} 10^{-2} \mathrm{H}$} \\
\hline & $\begin{array}{l}14 \\
21\end{array}$ & $\begin{array}{r}10 \\
9\end{array}$ & $\begin{array}{r}8 \\
30\end{array}$ & $\begin{array}{r}6 \\
20\end{array}$ \\
\hline & \multicolumn{2}{|c|}{ control } & \multicolumn{2}{|c|}{$\mathrm{KCN} 10^{-1} \mathrm{in}$} \\
\hline & $\begin{array}{r}19 \\
8\end{array}$ & $\begin{array}{r}12 \\
6\end{array}$ & $\begin{array}{r}20 \\
9\end{array}$ & $\frac{3 \cdot 3}{6}$ \\
\hline \multirow{2}{*}{$4 c_{0}^{\prime}$ glucose } & \multicolumn{2}{|c|}{ control } & \multicolumn{2}{|c|}{$\mathrm{KCI}: 10^{-1} \mathrm{M}$} \\
\hline & $\begin{array}{r}100 \\
44 \\
40\end{array}$ & $\begin{array}{l}92 \\
34 \\
36\end{array}$ & $\begin{array}{l}63 \\
30 \\
45\end{array}$ & $\begin{array}{l}60 \\
20 \\
26\end{array}$ \\
\hline \multirow[t]{2}{*}{$10 \%$ glucose } & 42 & 32 & 32 & 22 \\
\hline & \multicolumn{2}{|c|}{ control } & \multicolumn{2}{|c|}{$\operatorname{ICN} 10^{-0.5} \mathrm{~m}$} \\
\hline $4 \%$ glucose & $\begin{array}{r}41 \\
49 \\
100 \\
44 \\
40\end{array}$ & $\begin{array}{l}35 \\
42 \\
92 \\
34 \\
36\end{array}$ & $\begin{array}{l}21 \\
30 \\
76 \\
42 \\
37\end{array}$ & $\begin{array}{l}13 \\
20 \\
62 \\
28 \\
26\end{array}$ \\
\hline
\end{tabular}


TABLE 6.--Continued

$$
\text { control }
$$

$\operatorname{KCH} 10^{-0.5} \mathrm{M}$

$10 \%$ glucose

$$
\text { trial }
$$

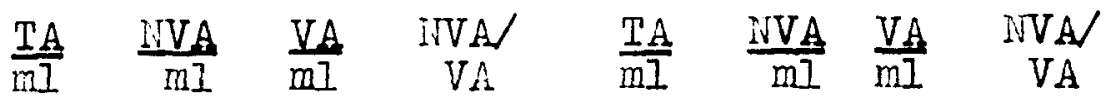

$\begin{array}{lllllllll}1 & 74 & 66 & 8 & 9: 1 & 24 & 14 & 10 & 2.0: 1\end{array}$

$\begin{array}{lllllllll}2 & 40 & 36 & 4 & 9: 1 & 14 & 10 & 4 & 2.5: 1\end{array}$

$\begin{array}{lllllllll}3 & 64 & 56 & 8 & 7: 1 & 40 & 34 & 6 & 5.7: 1\end{array}$

control

$\mathrm{KCIF} 10-0.25 \mathrm{M}$

$\begin{array}{lllllllll}1 & 44 & 32 & 8 & 4.0: 1 & 32 & 16 & 16 & 1.00: 1\end{array}$

$\begin{array}{lllllllll}2 & 48 & 38 & 10 & 3.8: 1 & 14 & 6 & 8 & 0.75: 1\end{array}$

$\begin{array}{lllllllll}3 & 38 & 23 & 10 & 2.8: 1 & 12 & 4 & 8 & 0.50: 1\end{array}$

$\begin{array}{lllllllll}4 & 38 & 34 & 4 & 8.5: 1 & 20 & 16 & 4 & 4.00: 1\end{array}$ 
Increasing the concentration to $10^{-0.5} \mathrm{M}$ did not have any effect on the activity of the inhibitor. In no case was atabrine as effective as cyanide (Table 7).

Atabrine and cyanide were also used in combination. Here the effect of Inhib1tion of the hexose-monophosphate shunt was about the same as with atabrine alone (Table 7). With nelther cyanide nor atabrine, nor with the combination of the two, was a complete blocking of the hexose-monophosphate shunt mechanism observed.

IV Results of Investigations with fructose as an inhibitor During the course of the investigation, repoits were released from the Department of Agricultural Blochemlstry at the Oh10 State UnIversity by Dr. John Gander Indicating that D-fructose might act as an inhibitor of some of the enzymes in the glycolytic pathway. These experiments were based on the use of lsolated enzymes, and not with living organisms.

This suggested that fructose might also act as an Inhibitor of glycolysis in the yeast cell, and invest1gations were begun on this phase of the profect. In theory, fructose might interfere with one of the first steps in 
TABLE 7.--Efiect of atabrine and potassium cyanide on acid production. Acidity is expressed as $\mathrm{ml} 0.1 \mathrm{~N}$ acid/ $100 \mathrm{ml}$. $\mathrm{TA}=$ total acidity; NVA = non-volatile acidity; $\mathrm{VA}=$ volatile acidity. Figures represent the average of three flasks in each trial. All cultures are on a ten per cent glucose basal medium.

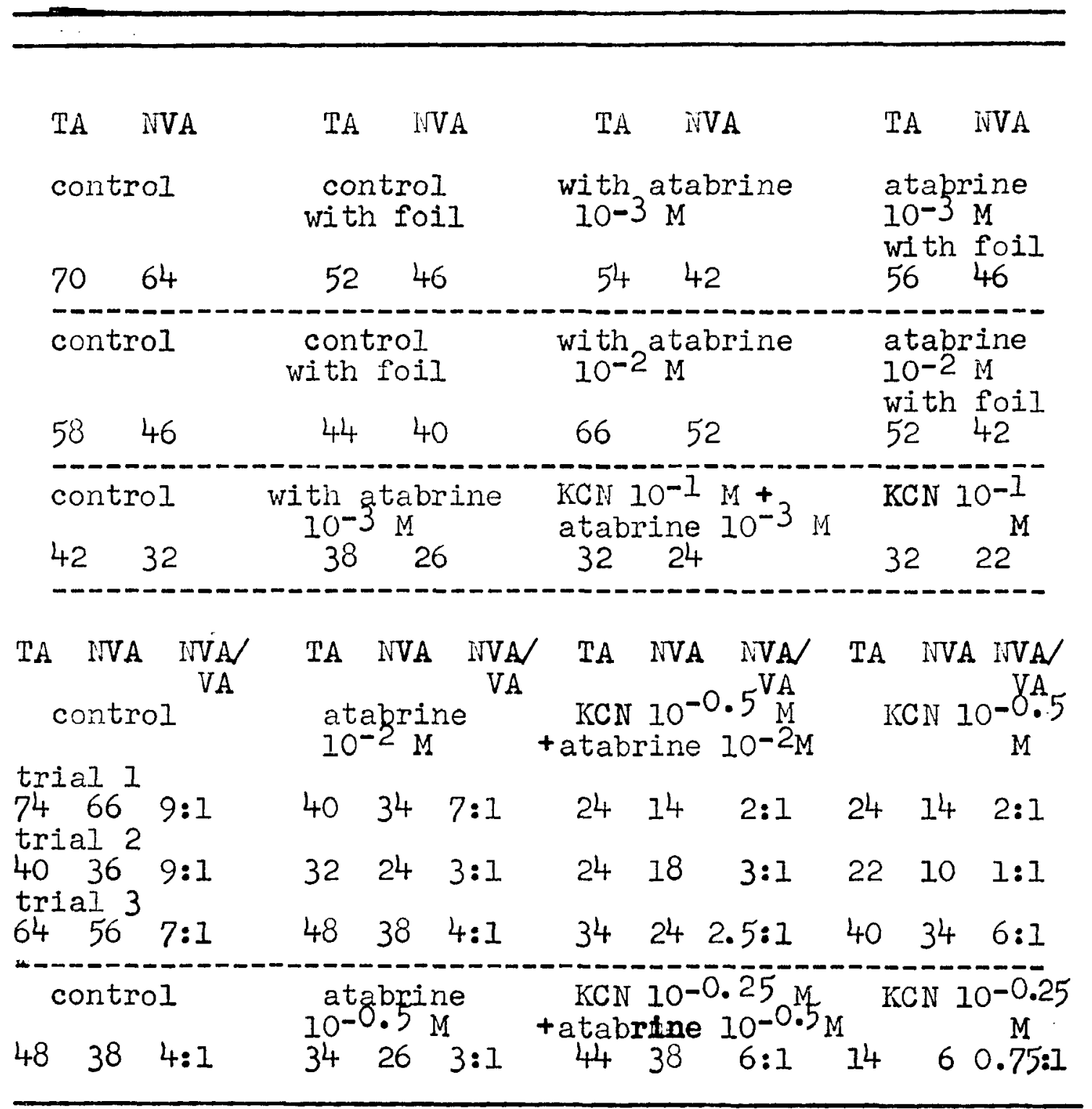


glycolysis, catalyzed by hexokinase; respiration would then occur through the hexose-monophosphate shunt mechanism, and an increase in non-volatile acld might be expected if this acid is formed through this pathway.

Investigations were set up using the standard 10 per cent glucose medium as a control, replacing 2 per cent of the glucose with D-fructose, and using a complete replacement of the glucose with 10 per cent D-fructose. On cultures grown on 10 per cent fructose, and also on those grown on a medium where 2 per cent fructose replaced the same amount of glucose, an increase in the number of cells was observed; there was an increase in total ac1d production; more non-volat1le ac1d was produced compared to the control; and production of volatile acld also increased.

Effect of varying concentrations of fructose. --A more intensive study was conducted using further gradations In relative concentration of glucose and fructose. As indicated in Table 8 , the results of these studies substantiated those of the preliminary tests. There was Increased total ac1d production when fructose 
replaced part of the glucose in the basal medium. Th1s Increase in total acid production did not become greater as more fructose was used. An increase in volatile ac1dity on fructose was noted in most cases; non-volatile ac1d production was higher on fructose in each case. Production of ethyl acetate decreased on media containing fructose as compared to the 10 per cent glucose control.

Observation of acid and acetate over a ten day period.-The next phase of the project was the determination of total ac1d, volatile and non-volat1le aclds, and ethyl acetate produced each day over a ten day period on 10 per cent glucose and 10 per cent fructose media. This was repeated fourteen times. These results are recorded in Table 9, and in Figures $1-6$.

Total acid production was higher on the fructose medium than on glucose. On fructose, total acldity reached a peak at seven days; on glucose, total acid continued to rise unt1l the tenth day. Volatile acid was considerably higher on fructose, where it continued to rise unt1l the tenth day. On glucose, volatile acid reached a peak at nine days. 
TABLE 8.--Effect of graded concentrations of glucose and fructose on acid and acetate production. $\mathrm{TA}=$ total acid; NVA $=$ non-volatile acid; $\mathrm{VA}=$ volatile acid .

\begin{tabular}{|c|c|c|c|c|}
\hline $\begin{array}{l}\text { percentage of } \\
\text { sugars in } \\
\text { basal medium }\end{array}$ & $\begin{array}{c}\text { TA } \\
\text { ml } \\
\text { (acidity } \\
0.1 \mathrm{NV}\end{array}$ & $\begin{array}{c}\text { VA } \\
\text { ml } \\
\text { expresse } \\
\text { cid per }\end{array}$ & $\begin{array}{r}\text { IVVA } \\
\text { ml } \\
\text { as ml } \\
0 \mathrm{ml})\end{array}$ & $\begin{array}{r}\text { acetate } \\
\text { milligrams }\end{array}$ \\
\hline \multirow{2}{*}{$\begin{array}{l}10 \% \text { glucose } \\
8 \% \text { glucose }+ \\
2 \% \text { fructose }\end{array}$} & 35.3 & 2.6 & 32.6 & \\
\hline & 45.6 & $7 \cdot 3$ & 38.3 & \\
\hline \multirow{2}{*}{$\begin{array}{l}10 \% \text { glucose } \\
6 \% \text { glucose }+ \\
4 \% \text { fructose }\end{array}$} & 33.0 & 6.0 & 27.0 & 316.8 \\
\hline & 41.0 & 7.0 & 34.0 & 156.6 \\
\hline \multirow{2}{*}{$\begin{array}{l}70 \% \text { glucose } \\
5 \% \text { glucose }+ \\
5 \% \text { fructose }\end{array}$} & 33.0 & 6.0 & 27.0 & 316.8 \\
\hline & 50.0 & 10.0 & 40.0 & 126.7 \\
\hline \multirow{2}{*}{$\begin{array}{l}10 \% \text { glucose } \\
4 \% \text { glucose }+ \\
6 \% \text { fructose }\end{array}$} & 42.0 & 8.0 & 34.0 & 332.6 \\
\hline & 54.0 & 8.0 & 46.0 & 119.7 \\
\hline \multirow{2}{*}{$\begin{array}{l}10 \% \text { glucose } \\
3 \% \text { glucose }+ \\
7 \% \text { fructose }\end{array}$} & 33.0 & 6.0 & 27.0 & 332.6 \\
\hline & 46.5 & 6.0 & 40.5 & 147.8 \\
\hline \multirow{2}{*}{$\begin{array}{l}10 \% \text { glucose d } \\
10 \% \text { fructose }\end{array}$} & 33.0 & 3.5 & 29.5 & 420.6 \\
\hline & 49.3 & 10.7 & 38.5 & 98.6 \\
\hline
\end{tabular}

a. average of three series; no acetate was determined

b. average of two series

c. an eight-day series; all others were seven-day

d. avenage of four series 
TABLE 9.--Acid and acetate production over a ten day period. Figures represent the average of fourteen series. $T A=$ total acid; $V A=$ volatile acid; $N V A=$ non-volatile acid.

days after

inoculation $20 \%$ glucose
$10 \%$ fructose

TA VA IVA acetate TA VA NVA acetate $\mathrm{ml} \quad \mathrm{ml} \quad \mathrm{mI} \quad \mathrm{mg} \quad \mathrm{ml} \mathrm{ml} \mathrm{ml} \quad \mathrm{mg}$

$\begin{array}{lllllllll}1 & 3.85 & \ldots & \ldots & 53.20 & 1.66 & \ldots & \ldots & 45.18 \\ 2 & 6.71 & \ldots & \ldots & 61.83 & 6.89 & \ldots & -- & 73.66\end{array}$

$\begin{array}{lllllllll}3 & 8.82 & 1.52 & 8.07 & 82.81 & 8.67 & 2.07 & 6.46 & 79.35\end{array}$

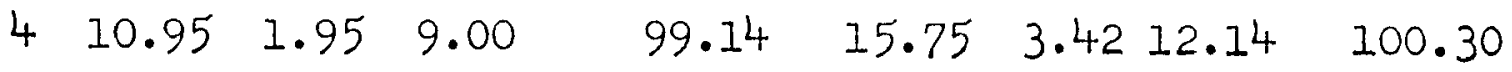

$\begin{array}{lllllllll}5 & 12.27 & 2.64 & 9.92 & 109.88 & 15.53 & 4.96 & 10.57 & 130.64\end{array}$

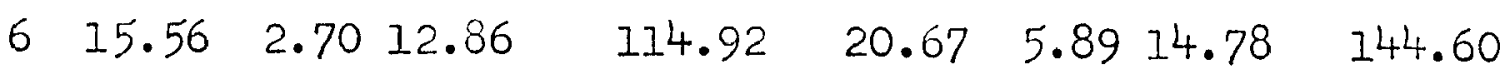

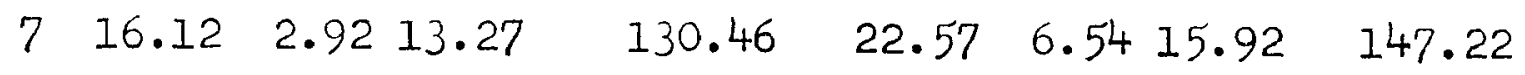

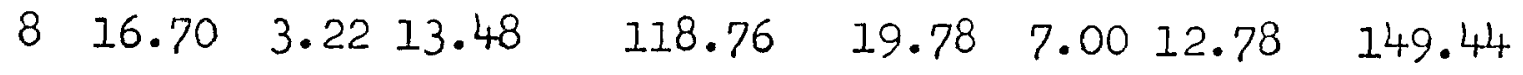

$\begin{array}{lllllllll}9 & 17.72 & 3.60 & 14.06 & 94.18 & 18.01 & 6.91 & 9.99 & 137.57\end{array}$

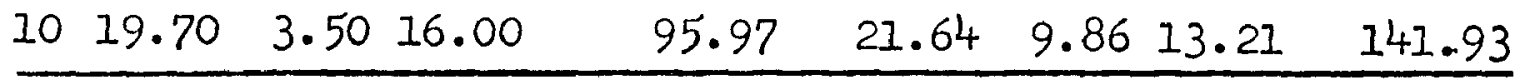




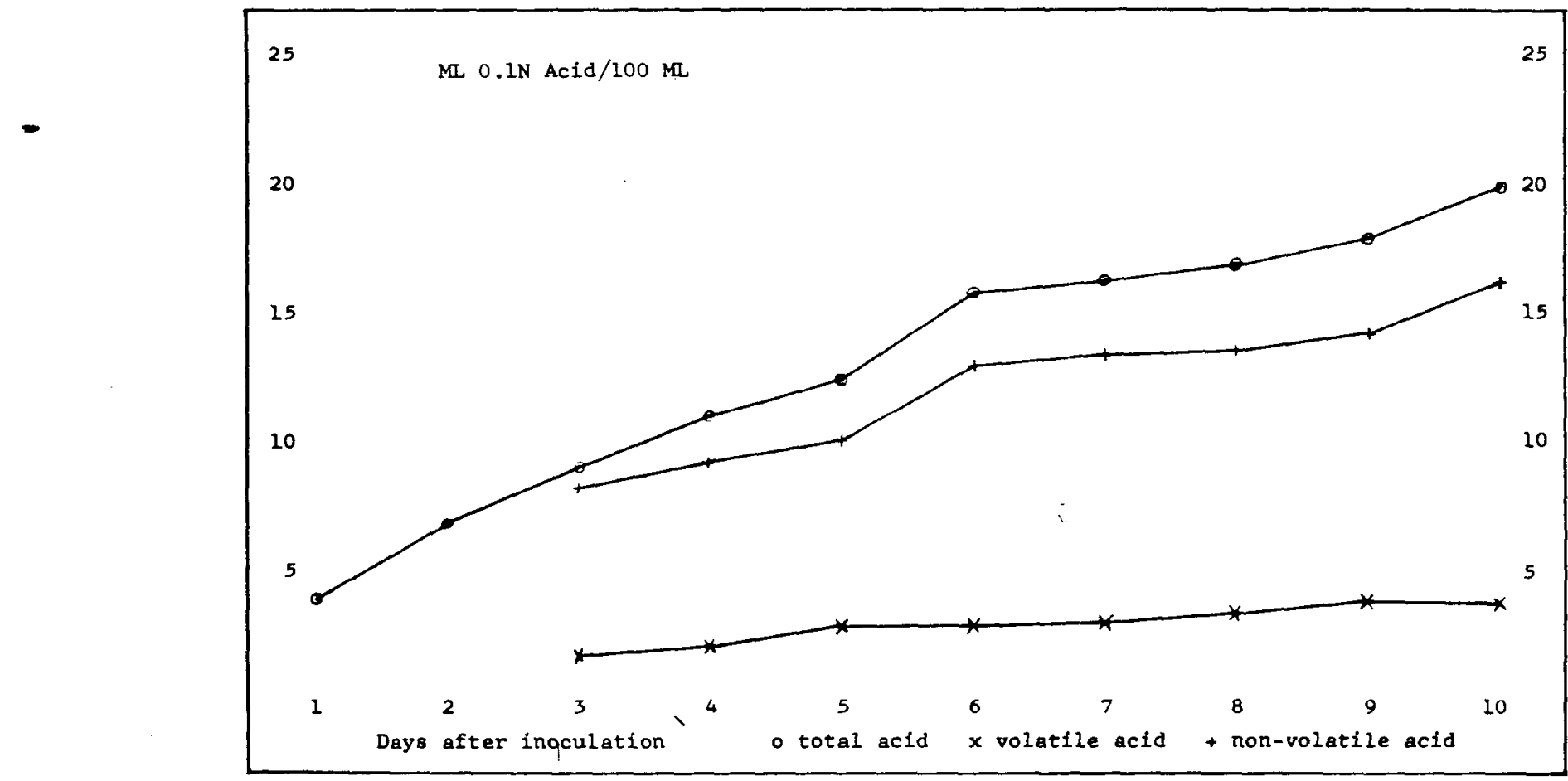

- Figure 1. -- Acid production on $10 \%$ glucose over a ten day period. Figures represent the average of fourteen series. 


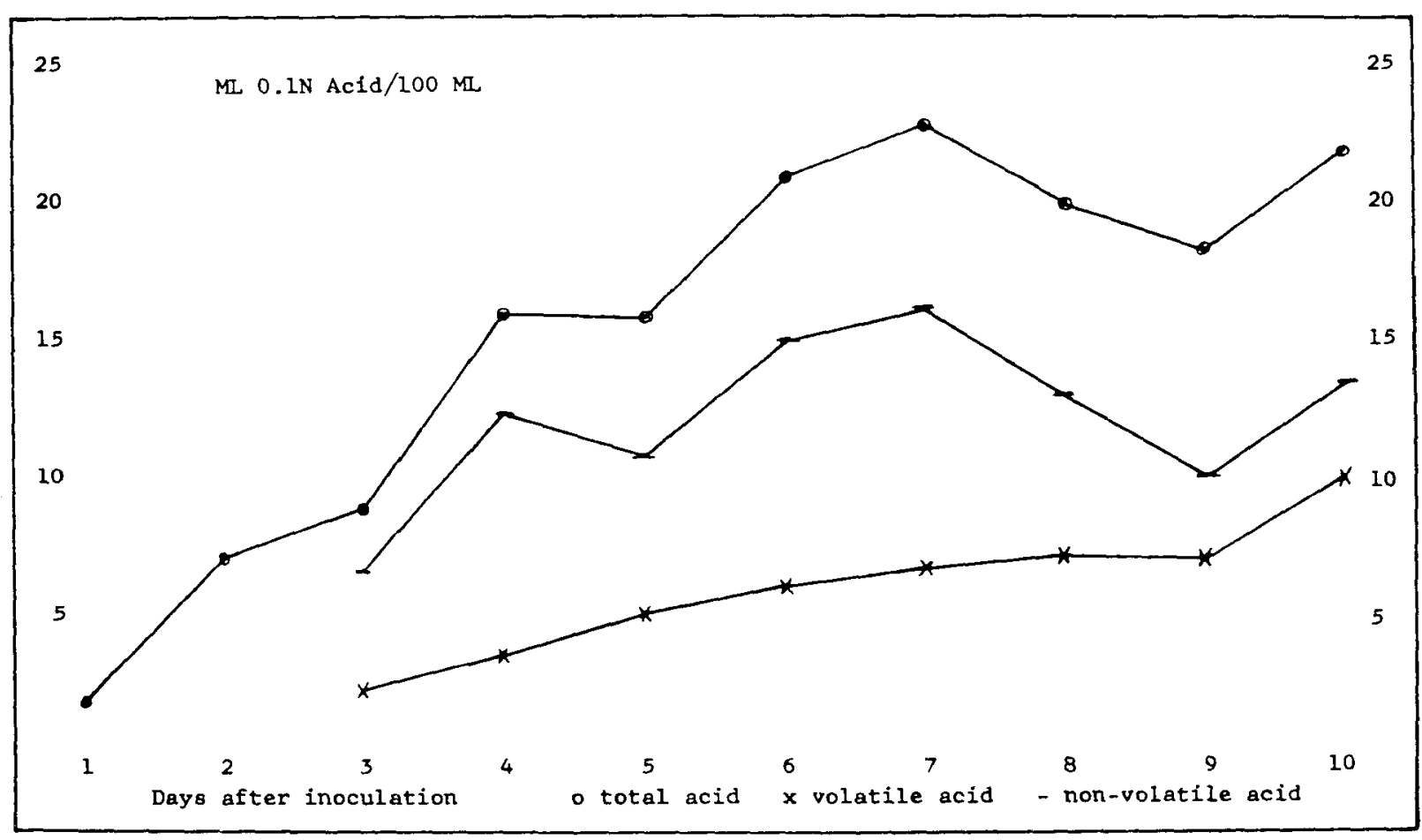

Figure 2. -- Acid production on $10 \%$ fructose over a ten day period. Figures represent the average of fourteen series. 


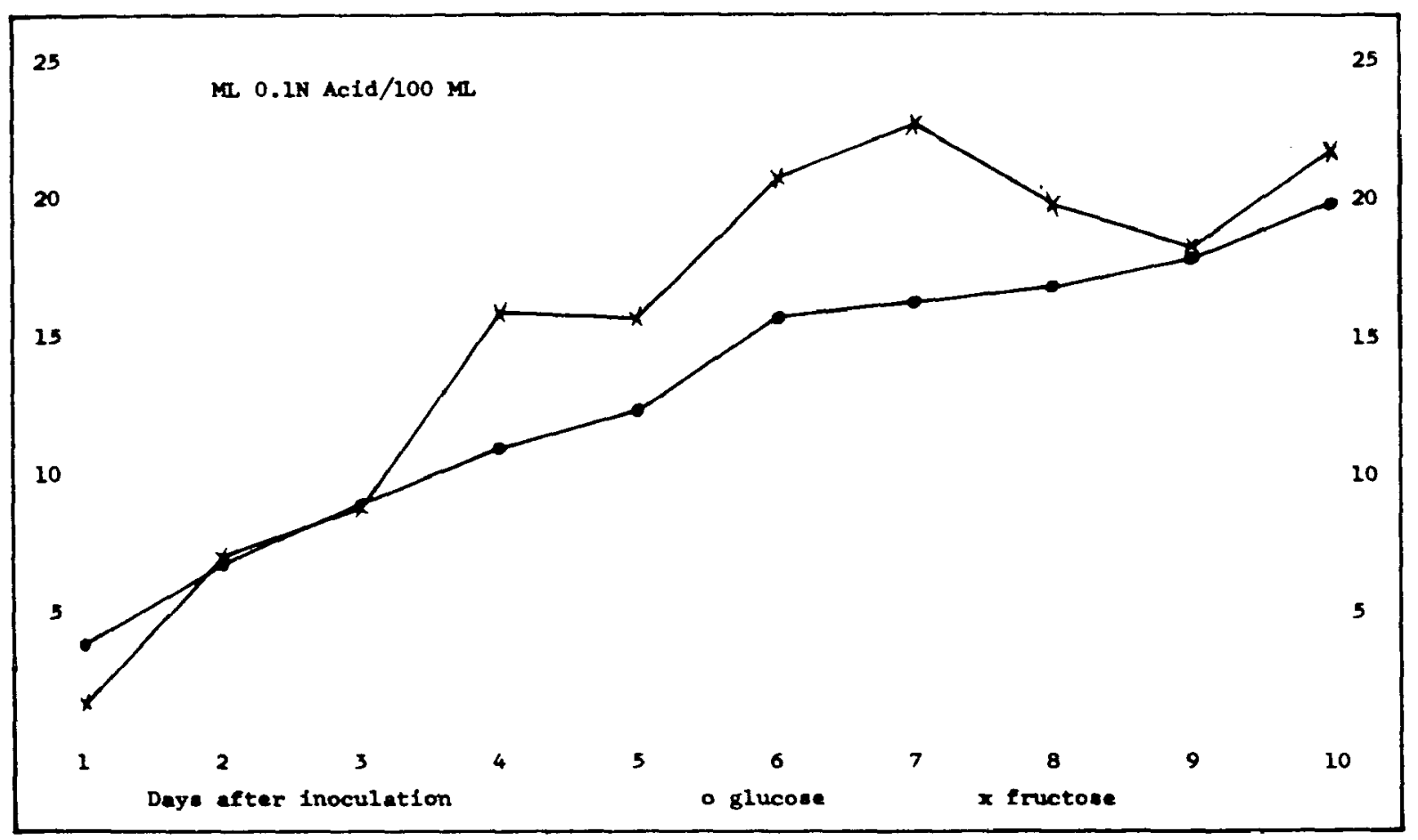

Figure 3. -- Production of total acid over a ten day period. Figuren represent the average of fourteen serfes. 


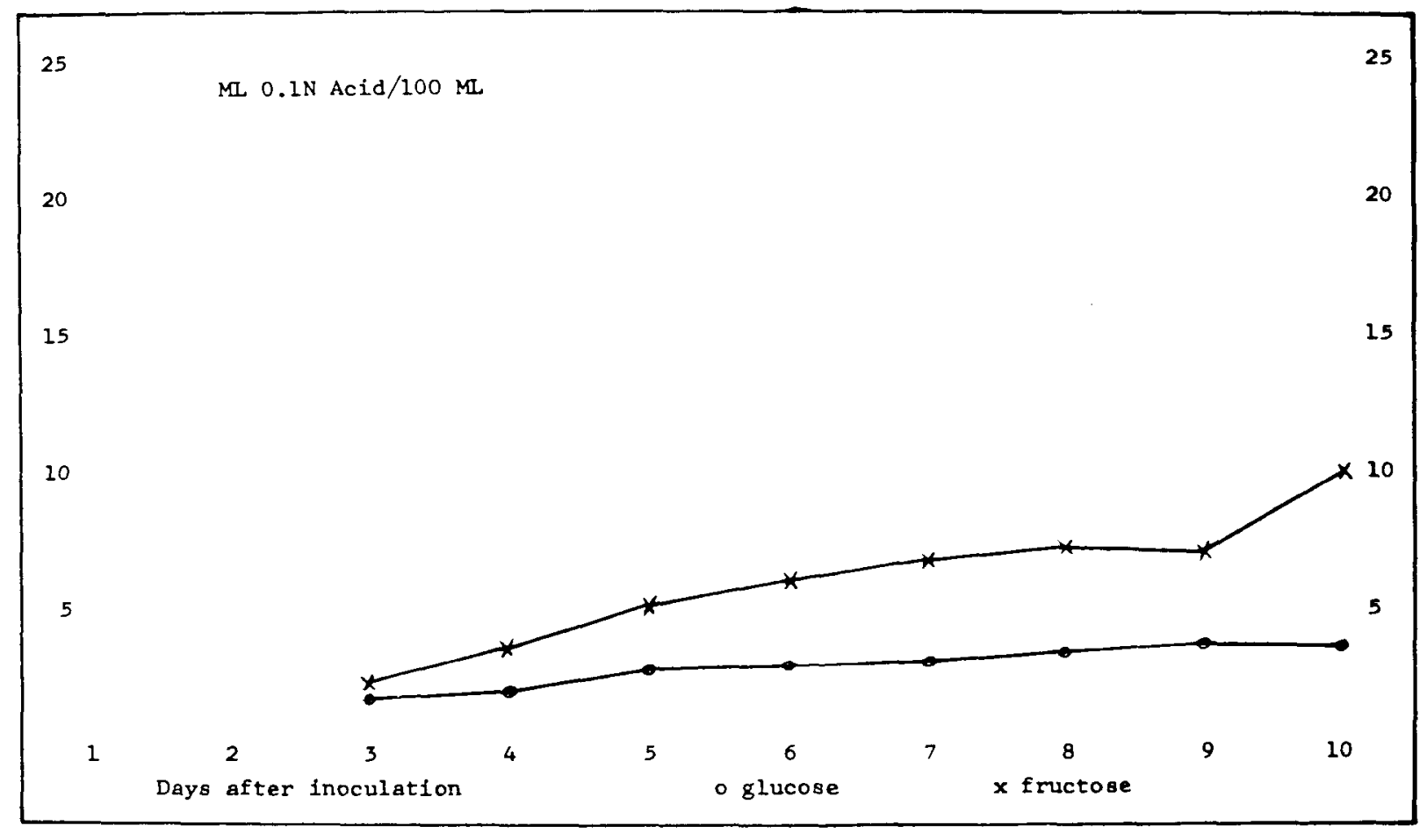

Figure 4. -- Production of volatile acid over a ten day period. Figures represent the average of fourteen series. 


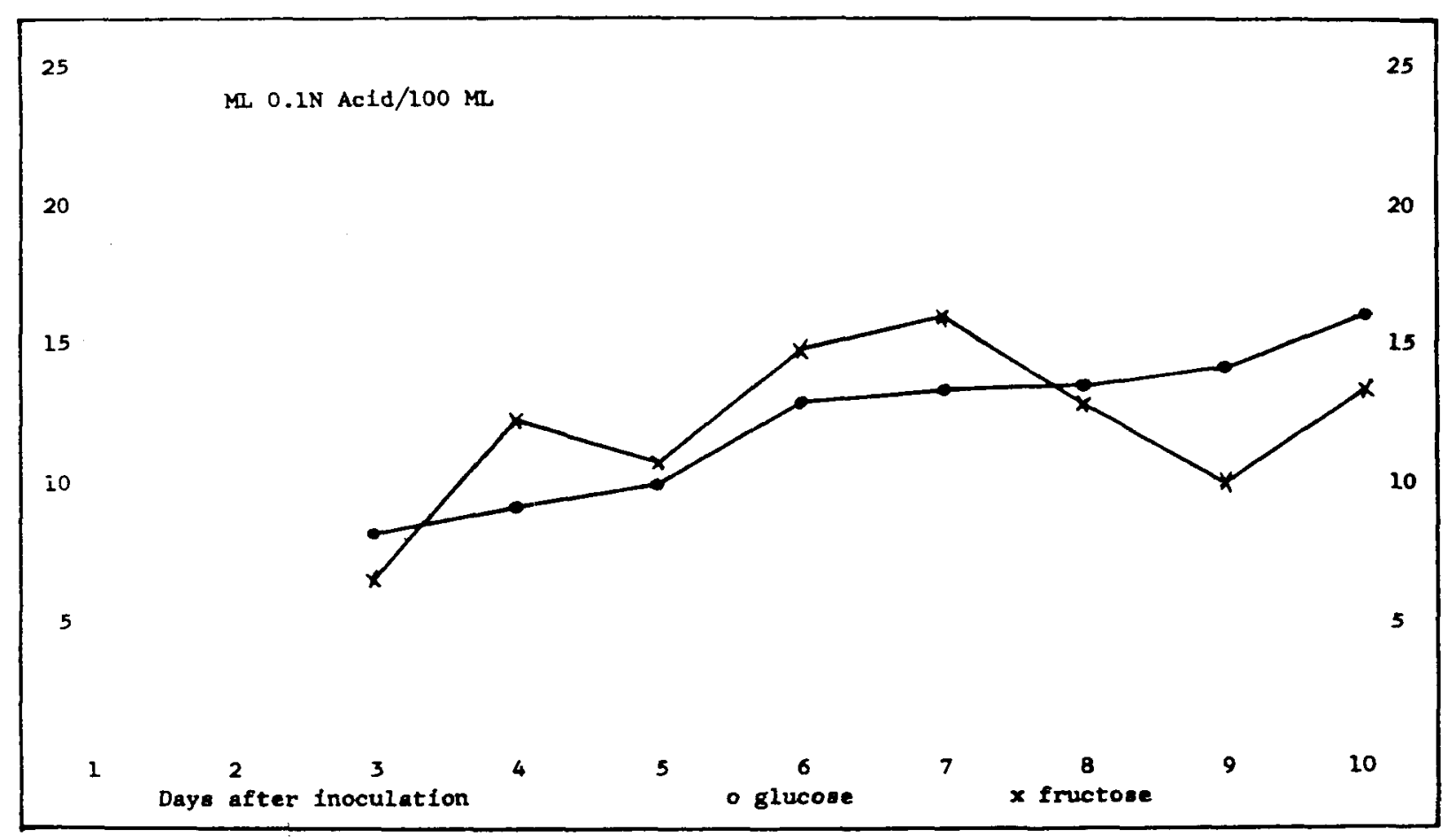

Figure 5. -- Production of non-volatile acid over a ten day period. Figures represent the average of fourteen eeries. 


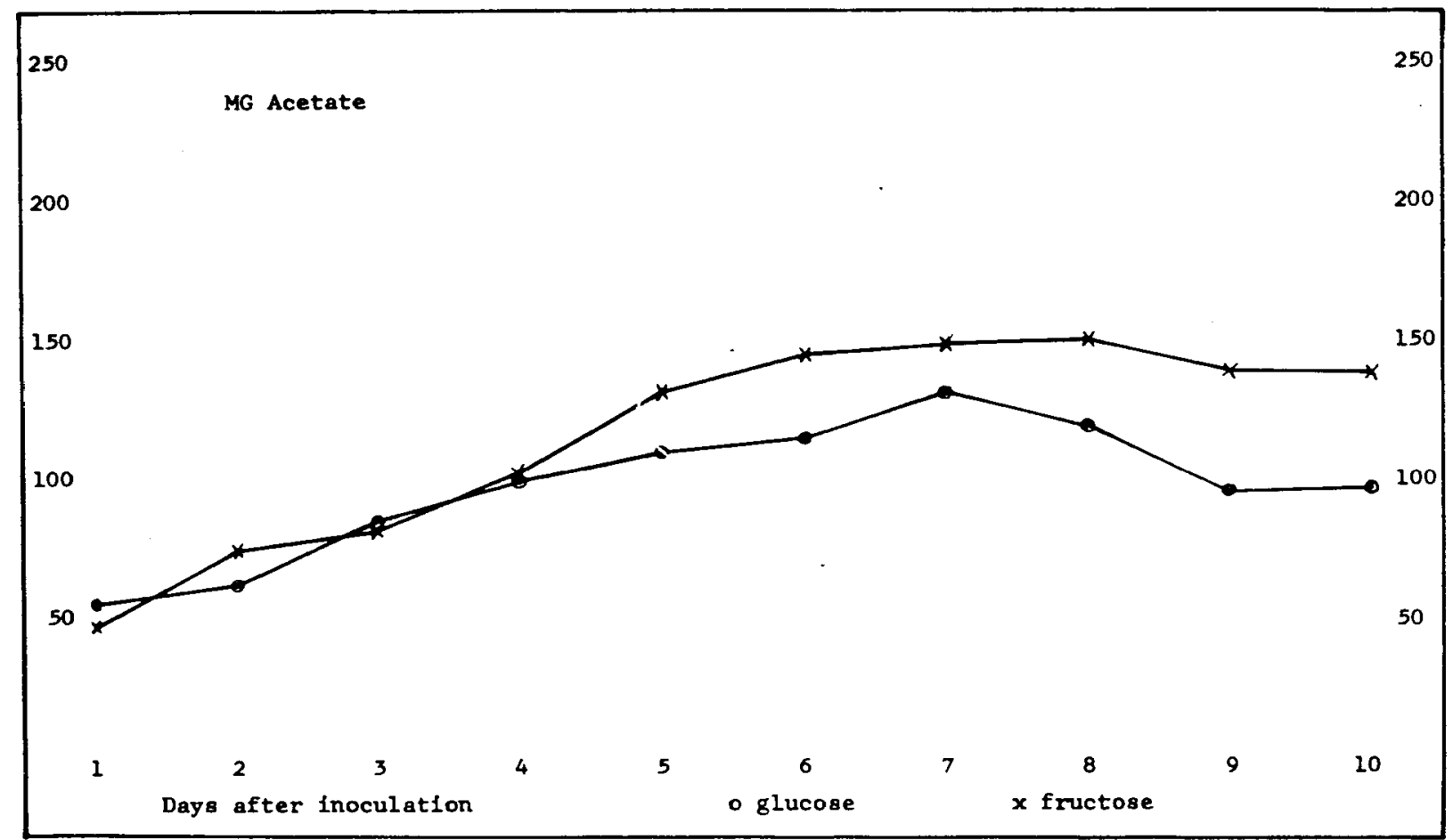

Figure 6. -- Ethyl acetate synthesis over a ten day period. Figures represent the average of fourteen series. 
Non-volatile acid production on the fructose medium reached a peak at seven days. This peak was approximately the same as the highest value for glucose, which was recorded at ten days.

Ethyl acetate production was higher on the medium containing fructose. On glucose, highest acetate production was at seven days; on fructose, at eight days. After seven days, acetate production on glucose fell off sharply. On fructose, acetate levels remained approximately the same until the end of the ten day perlod.

Levels of acid and acetate after twenty days.--A further experiment was conducted to investigate the levels of acid and ethyl acetate after a longer perlod of time. Ten flasks on each of the two media, 10 per cent glucose and 10 per cent fructose, were harvested after twenty days. The results of this experiment (Table 10) showed that the amounts of total acid reached similar levels after this perlod of time; non-volatile acid was slightly higher on the glucose medium, while volatile acid was slightly higher on the fructose medium. Acetate production was also higher on the fructose medium. 
Table 10.--Acid and acetate levels after twenty days. Figures represent the average of ten flasks for each medium. Initial pH was 6.3. $\mathrm{TA}=$ total acid; $\mathrm{VA}=$ volatile acid; $N \mathrm{NA}=$ non-volatile acid.

\begin{tabular}{ccccc}
\hline & TA & VA & NVA & acetate \\
& $\mathrm{mI}$ & $\mathrm{ml}$ & $\mathrm{ml}$ & $\mathrm{mg}$ \\
TRIAL 1 & & & & \\
$10 \%$ glucose & 24.0 & 8.0 & 16.0 & 122.20 \\
10\% fructose & 21.5 & 9.0 & 12.5 & 136.72 \\
& & & & \\
TRIAI 2 & & & & \\
$10 \%$ glucose & 23.0 & 5.0 & 18.0 & 116.26 \\
$10 \%$ fructose & 23.0 & 7.2 & 16.0 & 128.48 \\
& & & & \\
\hline
\end{tabular}


Comparing the levels at twenty days w1th those reached at the end of the ten day serles, It may be observed that levels of acid production had in general risen slightly, except for volatile acld production on fructose, which fell slightly from the ten day amount. Acetate production on glucose increased while acetate production on fructose was not as great at twenty days as at ten days. 


\section{DISCUSSION}

A scheme of glycolysis (Nord and We1ss, 1958) with the points of inhibition by the specific inhibitors Indicated might be represented as:

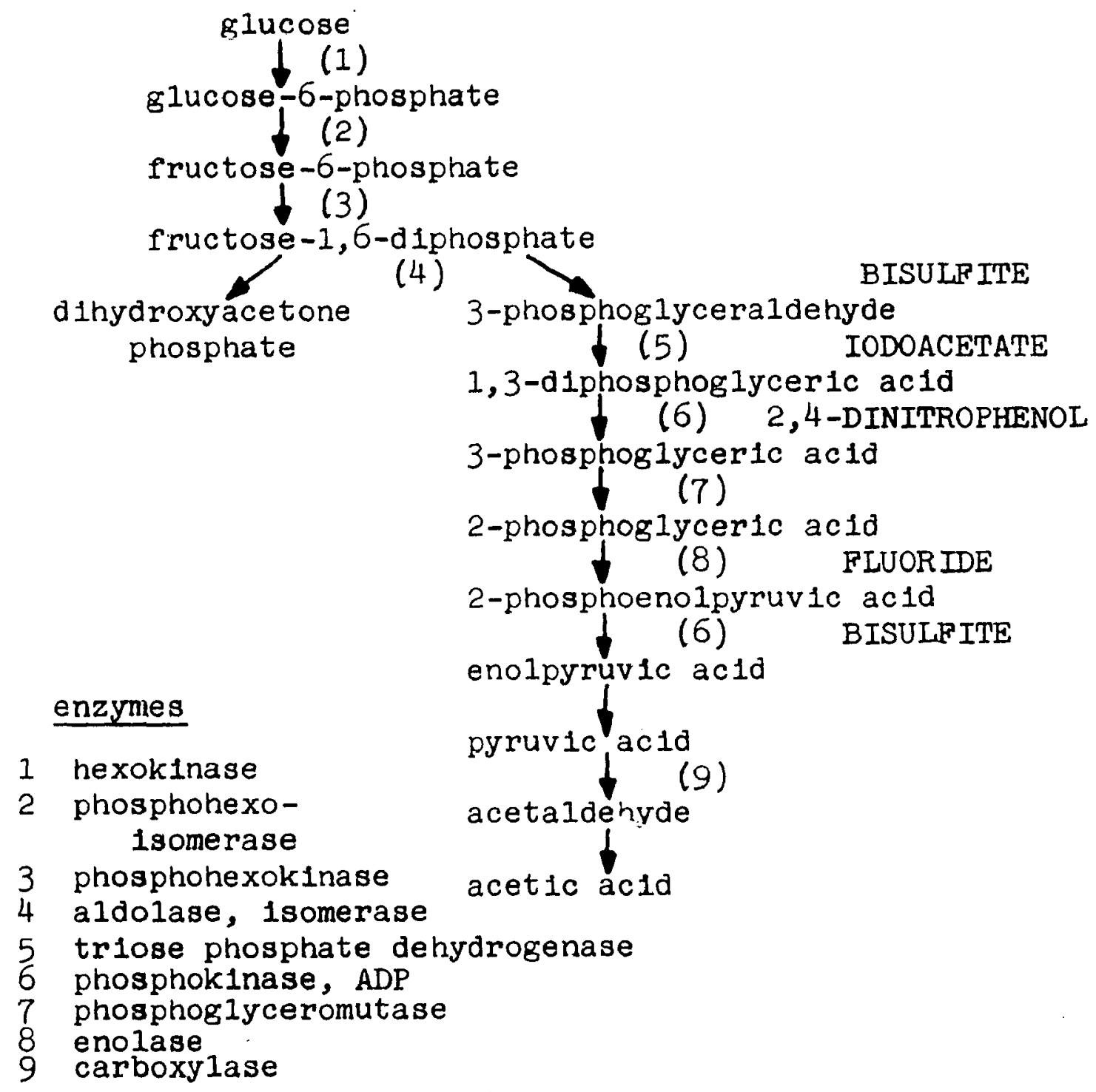

dinydroxyacetone phosphate

enzymes

1 hexokinase

2 phosphohexo-

Isomerase

3 phosphohexokinase

4 aldolase, isomerase

5 trlose phosphate dehydrogenase

6 phosphokinase, ADP

7 phosphoglyceromutase

8 enolase

9 carboxylase

(4) 3-phosphoglyceraldehyde

BISULP ITE IODOACETATE 1,3-d1phosphoglyceric acid (6) 2,4-DINITROPHENOL 3-phosphoglycertc acid (7)

2-phosphoglyceric acid (8) FIUORIDE

2-phosphoenolpyruvic acid $\downarrow(6)$ BISULPITE enolpyruvic acid 
Fluoride inhibits the enzyme enolase (number 8 in the diagram) by forming a complex w1th the magneslum ion attached to the enzyme and with phosphate, forming a protein-magnesium fluorophosphate.

$$
\text { 2,4-Dinitrophenol is called an "uncoupling agent." }
$$

It reduces the formation of ATP without affecting oxidation, or uncouples phosphorylation from oxidation. This would occur at step 6 , where ADP 1s changed to ATP, or at steps 1nvolving the conversion of 1,3-diphosphoglycer1c acid to 3-phosphoglyceric ac1d, and of 2-phosphoenolpyruvic acid to enolpyruvic acid.

Use of both fluoride and 2,4-dinitrophenol at concentrations of $10^{-4} \mathrm{M}$ resulted in an increase in non-volatile ac1d. This would indicate that glycolysis was blocked, with the increased non-volatile acid being produced by an alternate mechanism, possibly the hexosemonophosphate shunt.

Sodium bisulfite comblnes readily with aldehyde and ketone groups, and could thus combine with 3-phosphoglyceraldehyde produced in glycolysis. It also forms an addition compound with a molecule containing a carbonyl group and a 
double bond, as enolpyruvic ac1d contains. The possibility of its forming such a compound with enolpyruvic acid in glycolysis might account for the results obtained. No definite ratios of volatile and non-volatile acids were observed. It is possible that some of the intermediate products in glycolysis were tled up with bisulfite at some point. This might account for the varying amounts of total ac1d observed. Some of the most promising results came with the use of the sodium salt of lodoacetic acid. This poison is believed to 1nhibit triosephosphate dehydrogenase, an enzyme in the glycolytic pathway (number 5), by combining with free sulfhydry 1 groups on the enzyme.

Results with sodium lodoacetate would indicate that glycolysis is being blocked and that increased non-volatile acid is being produced by an alternate pathway, possibly the hexose-monophosphate shunt. Th1s proved to be the most effectlve of the compounds used to inhibit glycolysis. Inhibitors thought to affect the hexose-monophosphate pathway through the cytochrome system are cyanide and atabrine. 
If these are effect1ve inh1bitors, we might expect a low amount of non-volatile acid produced, with a corresponding increase in the amounts of volatile acid produced.

The hexose-monophosphate pathway and its relation to the cytochrome system (Lamanna and Mallette, 1953, and Axe1rod, 1960) might be 1ndicated as follows:

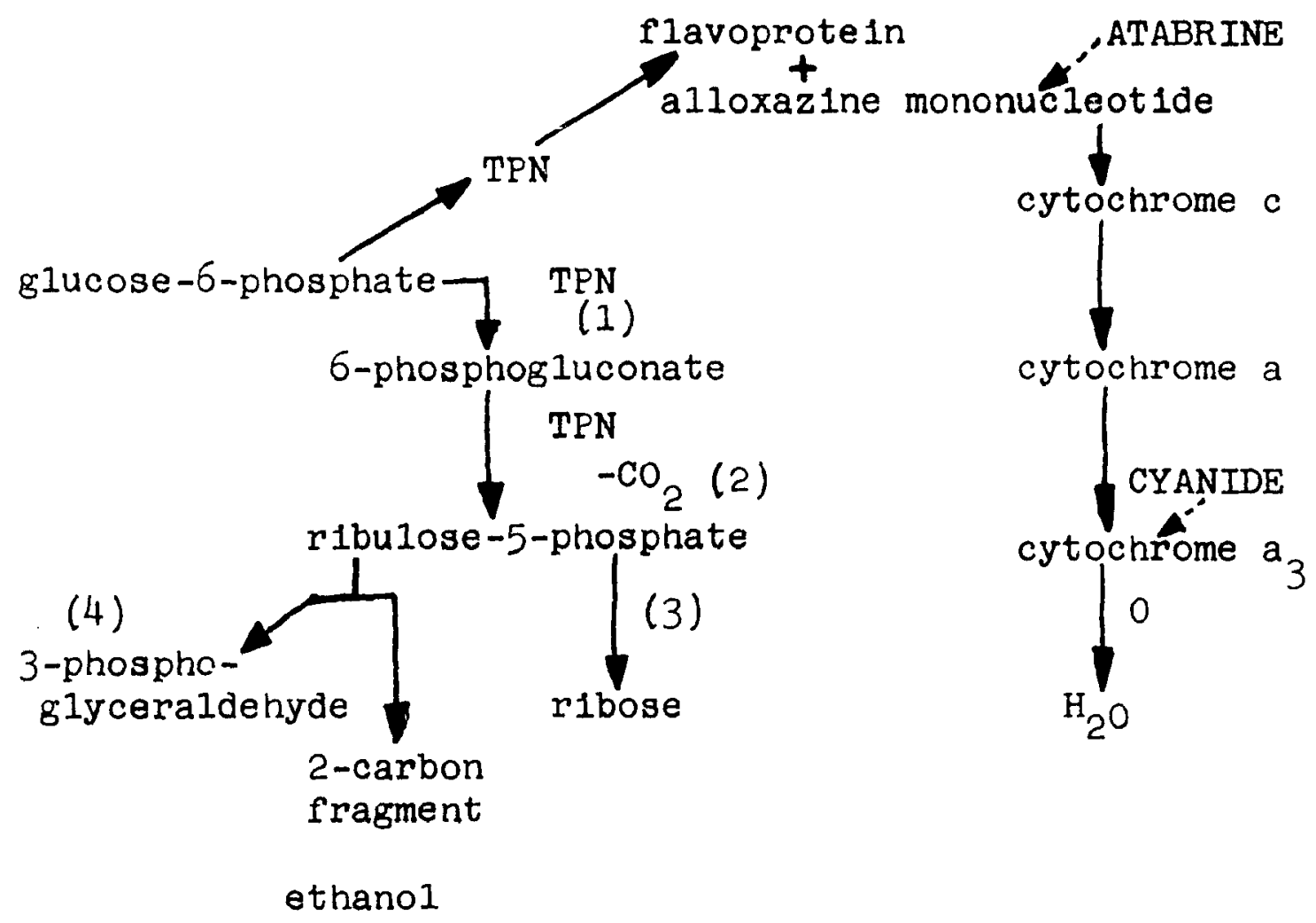

enzymes: 1 glucose-6-phosphate dehydrogenase or Zwischenferment

2 6-phosphogluconate dehydrogenase

3 phosphribo1somerase

4 transketolase 
Cyan1de Inhibits the enzyme cytochrome ox1dase, a1so known as cytochrome $a_{3}$, probably by combining with certain atoms in the prosthet1c group of the enzyme and thus preventing the enzyme from functioning normally. It w11l be noted that this inhibition occurs at the very end of the cytochrome system.

Some Indications of a low non-volatile acid/ volatile ac1d ratio were observed at concentrations of potassium cyanide from $10^{-5} \mathrm{M}$ to $10^{-0.25} \mathrm{M}$. Th1s effoct became pronounced at the greater concentrations. This might be interpreted as evidence that the hexose-monophosphate shunt is being blocked and that acld is being produced primarily through glycolysis.

Atabrine poisons the cytochrome system near the beginning, by Inhibiting an enzyme made up of a flavoprotein and a prosthet1c group called alloxazine mononucleotide. Atabrine competes with this prosthetic group for a place on the free protein, thus preventing formation of the complete enzyme system. Atabrine was observed to lower the non-volatile acid/volatile acid ratio at concentrations of $10^{-3} \mathrm{M}$ 
and $10^{-2} \mathrm{M}$. Increasing the concentration to $10-{ }^{0.5} \mathrm{M}$ did not have any observable effect on the activity of the inhibitor. Thus atabrine appeared to block the hexose-monophosphate shunt mechan1sm; however, in no case was atabrine as effective as cyanide. Atabrine and cyanide were also used in combination. Here the effect of inhibition of the hexose-monophosphate shunt was about the same as with atabrine alone. We may interpret this as demonstrating that the effects of cyanide and atabrine are not additive.

With nelther cyanide nor atabrine, nor with the combination of the two, was a complete blocking of the hexose-monophosphate mechanlsm observed.

Possible interpretation of results w1th fructose.--In general, production of total acid, volatile acid, and ethyl acetate were greated on 10 per cent fructose than on 10 per cent glucose at seven days and at ten days. Volatile acidity and ethyl acetate production continued to be greater at twenty days, with total acldity being about equal on the two media.

Non-volat1le acidity was greater on 10 per cent 
fructose from four to seven days; from elght to ten days and at twenty days non-volatile acid production on glucose became greater than that on fructose.

The increase in non-volatile acid on a medium with 10 per cent fructose at seven days appears to conf $1 \mathrm{rm}$ the theory that fructose may interfere with glycolysis at some point, and that the alternate pathway, the hexosemonophosphate shunt, might then produce increased nonvolatile acid.

An increase in volatile acid on the 10 per cent fructose medium, contributing to a greater total acid production than in the 10 per cent glucose control, might be due to the fact that some fructose is phosphorylated and subsequently acted on by glycolytic enzymes, finaliy producing volatile acetic acid.

In general, ethyl acetate production does not appear to be affected to any great extent by fructose. Early experiments indicated that acetate production was inhibited by fructose in the medium, but subsequent, more intensive experimental work djd not substantlate th1s.

Probably both pathways are operating simultaneously; when fructose is incorporated 1nto the medium, the 
principal part of respiration may be occurring through the monophosphate shunt, but some may be taking place through glycolys1s. Results would indicate that fructose does not completely block glycolysis, but may inhibit it to some degree.

The exact mechanism of this inhibition is unknown, but may be due to some interference with one of the first steps in glycolysis, where glucose would ordinarily be phosphorylated and converted to phosphorylated fructose. Fructose may inactivate the enzyme necessary for some of these conversions. The enzyme most likely to be involved 1s hexokinase.

The enzyme system responsible for the conversion of fructose-1,6-diphosphate has been found to be extremely sensitive towards oxidation and might be inhibited under aerobic conditions. Th1s suggests that yeasts follow a pathway other than glycolysis in breaking down carbohydrates aerobically.

It is possible that some internal changes in the aeration of the medium during the experimental period may influence the extent to which each pathway is used by the yeast. 
Fructose-6- phosphate can be catabolized via the hexose-monophosphate mechanism during aerobic oxidation. However, most evidence indicates that in living cells, glycolysis and not the hexose-monophosphate shunt is the prevaling mechanism for the utilization of glucose (Nord and We1ss, 1958).

The study of a purifled enzyme system may give much information about specificity of substrates and rates of reaction. However, the activity of the system in the living cell may differ from the results obtained with purified enzymes.

Results obtalned with a particular species may also differ from those of another species; it is difficult to draw general conclusions based on results with a particular specles. Genetic and environmental differences between specles may contribute to apparent variations in the predominance of one pathway or another.

The results from the investigations with fructose would Indicate that non-volatile acid may be produced by both a glycolytic mechan1sm and a hexose-monophosphate pachway. It is not possible to state that one pathway or 
the other is the predominant one by which non-volatile acid 1s produced.

It seems 1ikely that two or more metabolic pathways may be operating simultaneously in $\underline{H}$. anomala, with some interaction between the pathways being possible. 


\section{SUMMARY}

Results of the present investigation appear to indicate that in the yeast Hansenula anomala there are two pathways by which hexose may be ut1lized by the yeast ce11.

It was possible to block the glycolytlc pathway by using the inhibitors sodium lodoacetate, sodium fluoride, and 2,4-dinitrophenol, and thus increase the amount of non-volatile ac1d produced over that produced by the control without inhibitor. This would indicate that hexose metabollsm was occurring by an alternate pathway, possibly a hexose-monophosphate shunt mechan1sm. These three inhibitors are known to inhibit glycolysis at three specific steps in the pathway; it may be significant that the best results were obtained by using sodium lodoacetate, which affects one of the earlier steps in the pathway, the conversion of 1,3-d1phosphoglyceraldehyde to 1,3-diphosphoglyceric acid. None of the inhibitors 
effected a complete blocking of glycolysis, although the production of volatile ac1d was reduced.

Conversely, experiments were designed to reduce the amount of non-volatile acld produced by the hexose-monophosphate shunt. In this case the inhibitors used were potassium cyanide and atabrine. Both of these appeared to inhibit the shunt mechan1sm to some extent, with potassium cyanlde proving more effective. Here, increased volatile ac1d, presumably produced by glycolysis, resulted; again, it was not possible to block the pathway completely. These two inh1b1tors are known to affect the shunt mechanism at two separate points, with cyanide inhibiting a later reaction in the pathway than atabrine.

These results would Indicate that two alternate pathways exist in the metabollsm of $\underline{H}$. anomala. Under certain conditions it is possible that one or the other pathway may operate alone; results from the present study would indicate, however, that the pathways more of ten are involved simultaneously. Perhaps the best evidence for this was obtalned from the results using fructose as an inhibitor.

Fructose differs markedly from the other inhibitors 
used in that it is a sugar very similar to glucose, rather than a metabolic poison like the inhibltors used earlier. Previous research indicates, however, that fructose may act in some way as an inhibitor of glycolysis.

The present results indicate that fructose may Interfere with glycolysis, since an early increase in nonvolatile acld is evident. Apparently when glycolysis is Inhibited, respiration occurs through the alternate shunt mechanism. At the same time, an increase in volatile acld was also noted. This might be due to a phosphorylation of the fructose and 1ts Incorporation into the glycolytic pathway. The greater total acid production on fructose over that on glucose might then be due to the fact that both pathways are operating simultaneously. It is not possible to state that the hexose-monophosphate shunt is the predominant avenue for resplration in the yeast cell on a medium containing fructose.

The studies with fructose also point to some interaction between the two pathways, with fructose being converted to glucose and then belng metabolized through 
the shunt mechanism, after one of the first steps in glycolysis is impeded by the presence of fructose. The reverse reaction, the conversion of phosphorylated glucose to fructose-6-phosphate, is an early step in glycolysis. It is also possible that further interaction between the two pathways occurs. 


\section{LITERATURE CITED}

Alexopoulos, C.J. 1952. Introductory Mycology. New York: John Wiley and Sons.

Axelrod, Bernard. 1960. Chapter 3 (Glycolysis) and Chapter 5 (Other Pathways of Carbohydrate Metabolism), in Metabolic Pathways, Volume 1 , edited by David M. Greenberg. New York: Academic Press.

Brock, T.D. 1952. Studies on the metabolism of the yeast, Hansenula anomala (Hansen) Sydow. Ph.D. dissertation, the Ohio State University.

Cook, A.H. 1958. The Chemistry and Biology of Yeasts. New York: Academic Press.

Davies, R.,E.A.Falkner, J.F. Wilkinson, and J.L. Peel. 1951. Ester formation by yeasts. 1. Ethyl acetate formation by Hansenula species. Biochem. Jour. 49: 58-61.

Davis, Norman D. An initial study of pathways of carbon metabolism in Hansenula anomala (Hansen) Sydow. 1958. Mycologia L, No. 5: 770-776.

Gray, William D. 1949. Initial studies on the metabolism of Hansenula anomala (Hansen) Sydow. Amer. Journ. Bot. 36:475-480.

Greenberg, David M., editor. 1960. Metabolic Pathways, Volume 1. New York: Academic Press.

Guilliermond, A. 1937. La sexualite, le cycle de dèveloppement, la phylogenie, et la classification des levures d apres les travaux recents. Paris: Masson et Cie.

Guilliermond, A. 1940. Sexuality, developmental cycle, and phylogeny of yeasts. Bot. Rev. 6: 1-24. 
Haas, E., B.L. Horecker, and T.R. Hogness. 1940. The enzymatic reduction of cytochrome $c$. J. Biol. Chem. 136: 747-774.

Horecker, B.L., and A.H. Mehler. 1955. Carbohydrate metabolism. Ann. Rev. Biochem. 24: 207-274.

Hughes, S.B. 1952. Acidic metabolic products of Hansenula anomala. Mycologia 44: 736-747.

Kuehner, C.C. 1951. The effect of B-vitamins and trace elements on the growth and ester production of Hansenula anomala. Mycologia 43: 389-401.

Lamanna, C., and M.F. Mallette. 1953. Basic Bacteriology. Baltimore: Williams and Wilkins.

Lipmann, F. 1944. The enzymatic synthesis of acetyl phosphate. J. Biol. Chem. 155: 55-70.

Lipmann, F. 1955. Coenzyme A and biosynthesis. American Scientist 43: 37-47.

Lipmann, F., and L.C. Tuttle. 1945. The detection of activated carboxyl groups with hydroxylamine as interceptor. J. Biol. Chem. 161: 415-416.

Lodder, Jacomina, and N.J.W. Kreger-van Rij. 1952. The Yeasts, a Taxonomic Study. Amsterdam: N. Holl and Publis hing Co.

Lodder, Jacomina, W. Ch. Slooff, and N.J.W. Kreger-van Rij. 1958. Chapter 1 (The Classification of Yeasts) in The Chemistry and Biology of Yeasts. Ed. by A.H. Cook. New York: Acadernic Press.

Nord, F.F., and S. Weiss. 1958. Chapter 7 (Fermentation and Respiration) in The Chemistry and Biology of Yeasts. Ed. by A.H. Cook. New York: Academic Press.

Novelli, G.D., and F. Lipmann. 1947. The involvement of coenzyme $A$ in acetate oxidation in yeasts. J. Biol. Chem. 171: 833-834.

Peel, J.L. 1951. Ester formation by yeasts. 2. Biochem. Jour. 49: 62-67. 
Sova, C.R. 1960. Metabolic pathways in ethyl acetate production in Hansenula anomala. Ph.D. dissertation, the Ohio State University.

Tabachnick, Joseph. 1951. The chemistry and physiology of ester production by Hansenula anomala. Ph.D. dissertation, University of California.

Wickerham, L.J. 1951. Taxonomy of yeast. U.S. Dept. Agr. Tech. Bull. Number T. 1029.

Wickerham, L.J., and K.A. Burton. 1954. A simple technique for obtaining mating types in heterothallic diploid yeasts with special reference to their uses in the genus Hansenula. J. Bacteriol. 67: 303-308.

Wolf, F.A., and F.T. Wolf. 1948. The Fungi. Volumes $I$ and II. New York: John Wiley and Sons. 


\section{AUTOBIOGRAPIYY}

I, Janet Posey Toy, was born in Follansbee, West Virginia, on June 7, 1930, the daughter of Clyde D. and Marie Posey. I attended public schools in that community, and received the degrees Bachelor of Arts and Naster of Science from West Virginia University, at Morgantown, in 1951 and 1952 respectively. While working toward the Master's degree, I was a teaching assistant in biology and a research assistant to Dr. V. G. Lilly and Dr. H. I. Barnett in the field of physiology of fungi. From 1952 until 1959 I taught in public high schools in weirton and Follansbee, West Virginia, and Germantown, Ohio. In 1957 I began to work toward the degree Doctor of Philosophy at the Ohio State University under an Academic Year Institute grant from the National Science Foundation. In 1958 I was married to William Minor Toy. From 1959 until 1961 I was a member of the biology faculty at Wittenberg University, Springfield, Ohio, in which city I now reside. 